
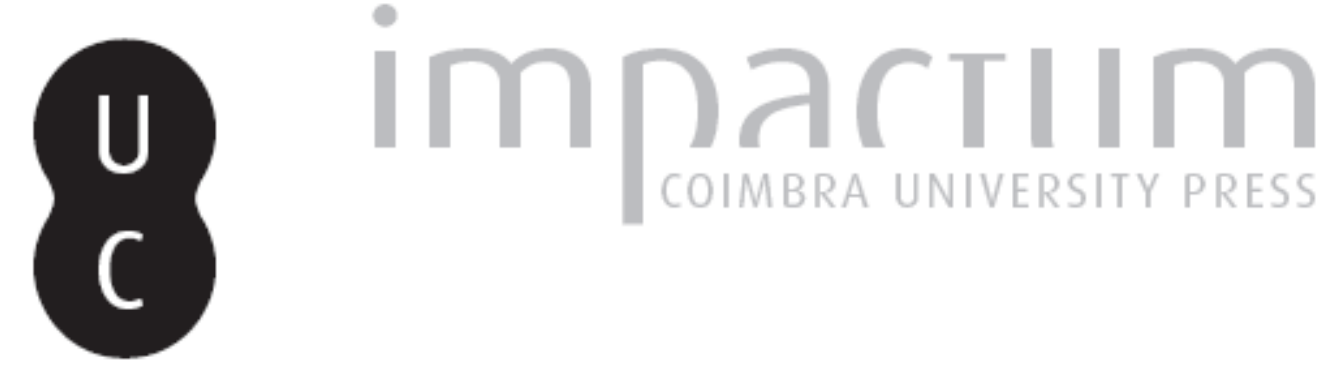

\title{
Do Cancioneiro da Ajuda ao «Livro das Cantigas» do Conde D. Pedro: análise do acrescento à secção das cantigas de amigo de
}

Autor(es): Oliveira, António Resende de

Publicado por: Imprensa da Universidade de Coimbra

URL persistente:

URI:http://hdl.handle.net/10316.2/43798

DOI:

DOI:https://doi.org/10.14195/2183-8925_10_38

Accessed : $\quad$ 26-Apr-2023 11:23:59

A navegação consulta e descarregamento dos títulos inseridos nas Bibliotecas Digitais UC Digitalis, UC Pombalina e UC Impactum, pressupõem a aceitação plena e sem reservas dos Termos e Condições de Uso destas Bibliotecas Digitais, disponíveis em https://digitalis.uc.pt/pt-pt/termos.

Conforme exposto nos referidos Termos e Condições de Uso, o descarregamento de títulos de acesso restrito requer uma licença válida de autorização devendo o utilizador aceder ao(s) documento(s) a partir de um endereço de IP da instituição detentora da supramencionada licença.

Ao utilizador é apenas permitido o descarregamento para uso pessoal, pelo que o emprego do(s) título(s) descarregado(s) para outro fim, designadamente comercial, carece de autorização do respetivo autor ou editor da obra.

Na medida em que todas as obras da UC Digitalis se encontram protegidas pelo Código do Direito de Autor e Direitos Conexos e demais legislação aplicável, toda a cópia, parcial ou total, deste documento, nos casos em que é legalmente admitida, deverá conter ou fazer-se acompanhar por este aviso.

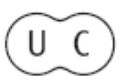


REVISTA DE HISTORIA DAS IDEIAS IO
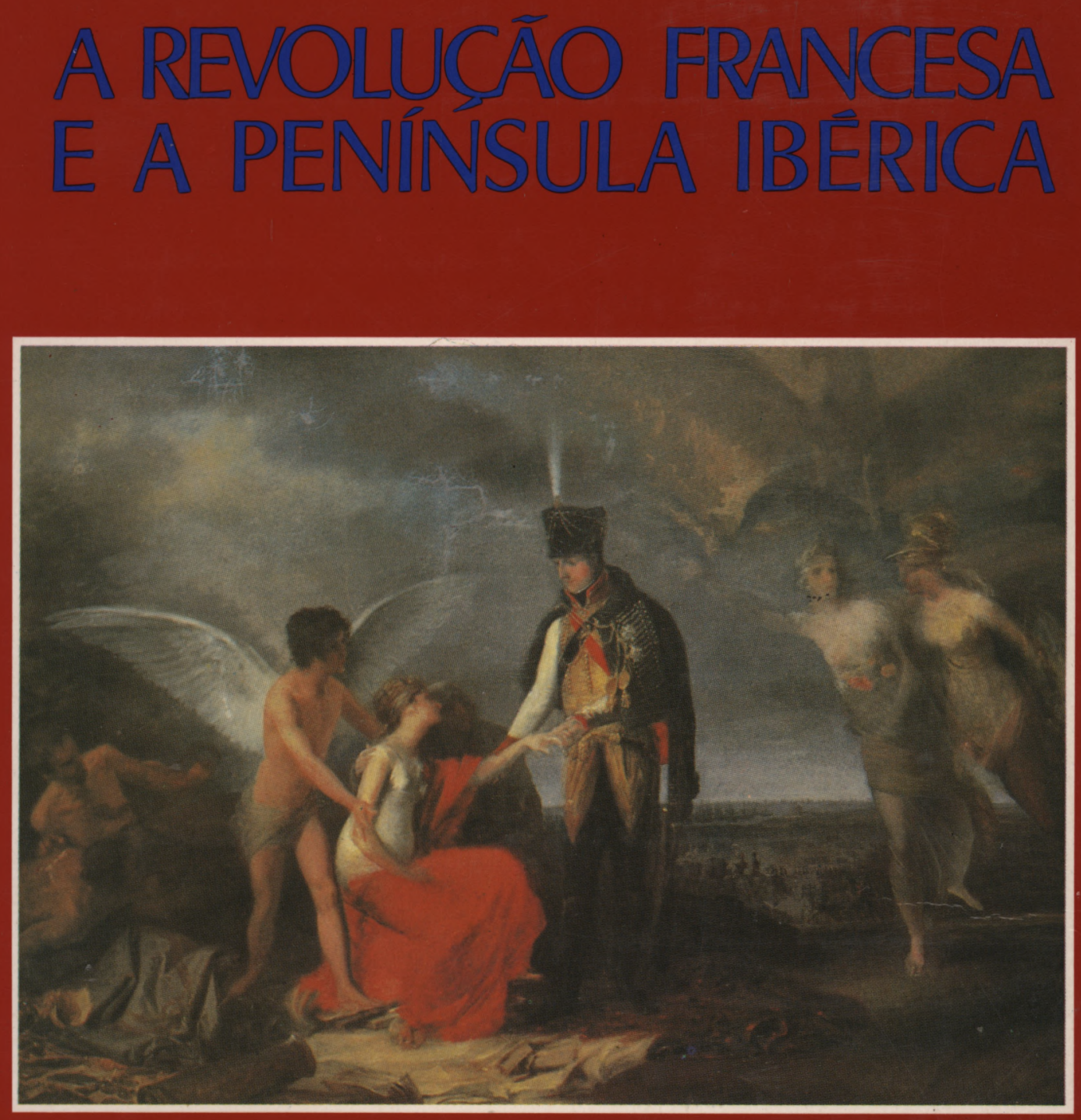

INSTITUTO DE HISTÖRIA E TEORIA DAS IDEIAS FACULDADE DE LETRAS 


\section{DO CANCIONEIRO DA AJUDA AO «LIVRO DAS CANTIGAS» DO CONDE D. PEDRO}

Análise do acrescento à secção das cantigas de amigo de $\omega * *$

\section{Introdução}

«Item mando o meu Livro das Cantigas a El Rey de Castella». O conde D. Pedro fazia assim, no seu testamento de $1350\left({ }^{1}\right)$, a primeira referência conhecida, até ao momento, à organização em livro das composições dos trovadores galego-portugueses cantadas nos paços senhoriais e régios do ocidente peninsular a partir dos fins do séc. XII. Atendendo à data em que é mencionado, e sabendo nós da sua coincidência com o epílogo desta manifestação cultural, tratar-se-á, sem dúvida, de uma compilação final, reunindo não só trovadores do séc. XIII, mas também aqueles cuja obra pode ser situada na primeira metade do séc. XIV $\left.{ }^{(2}\right)$.

* Faculdade de Letras da Universidade de Coimbra.

** «De $\omega$ ao 'Livro das Cantigas' do conde D. Pedro», tal deveria ser o título do trabalho que apresentamos. Conscientes, no entanto, da pouca atenção que o meio historiográfico português tem prestado a esta manifestação cultural, optamos por um título menos enigmático e aceitável também, segundo cremos, de um ponto de vista cronológico.

A sua redacção final foi melhorada graças às sugestões, sempre estimulantes, do Professor Doutor José Mattoso. Pudemos também beneficiar da leitura atenta do original feita, em Roma, pelo Professor Doutor Giuseppe Tavani a quem agradecemos a amabilidade com que nos recebeu. Este frutuoso contacto somente foi possível em virtude da bolsa de estudo que nos foi atribuída, ao abrigo de um convénio celebrado entre o INIC e o CNR italiano.

(1) Publ. por A. Caetano de Sousa, Provas da História Genealín gica da Casa Real Portuguesa (ed. revista por M. Lopes de Almeida e C. Pegado), I, Coimbra, 1946, pp. 1747 (cit. p. 176).

(2) Esta questão tem sido inserida no contexto mais geral da tentativa de esclarecimento da tradição manuscrita da lírica galego-portuguesa. A hipótese foi avançada já por Teófilo Braga e caucionada 
Apesar da sua importância estamos, neste caso, perante um testemunho indirecto acerca da tradição manuscrita trovadoresca, numa altura em que a função destes autores perdia a sua eficácia nos círculos cortesãos em que se desenvolvera. Dois outros testemunhos, estes directos, permitem-nos ter uma ideia mais exacta dessa tradição num momento em que a cultura trovadoresca se impunha ainda como sinal mais evidente aa existência de uma cultura nobiliárquica no noroeste peninsular. Referimo-nos ao "Cancioneiro da Ajuda» e ao chamado «Pergaminho Vindel» ( ${ }^{3}$ ), o primeiro (A) contendo apenas «cantigas de amor» de trovadores do séc. XIII, na sua maioria portugueses, o segundo (N), uma «folha volante» contendo as sete «cantigas de amigo» de Martim Codax, jogral galego também do séc. XIII, acompanhadas da respectiva notação musical $\left({ }^{4}\right)$. Perante os autores neles inseridos e levando também em consideração as semelhanças paleográficas já anotadas entre ambos, a sua feitura tem sido colocada nos finais do séc. XIII $\left(^{5}\right)$.

Giuseppe Tavani, a quem se deve a mais recente sistematização dos nossos conhecimentos neste domínio $\left.{ }^{\beta}\right)$, assinalou já, e justificou, a pobreza da tradição manuscrita peninsular quando comparada com os 95 cancioneiros provençais, os cerca

por C. Michaëlis de Vasconcelos, Cancioneiro da Ajuda, II, Halle, 1904, em particular pp. 243-53 (a partir de agora, Michaëlis, $C A$ ), e tem merecido apoio unänime da crítica: v. introd. de L.F. Lindley Cintra ao Cancioneiro Português da Biblioteca Vaticana (cód. 4803), reprodução fácsimilada, Lisboa, 1973, pp. XIV-XV; e Giuseppe Tavani, «La poesia lirica galego-portoghese», in Grundriss der Romanischen Literaturen des Mittelalters, vol. II, t. I, fasc. 6, Heidelberg, 1980, p. 35 (a partir de agora Tavani, Grundriss). Uma rápida síntese com o estado da questão sobre o problema da tradição manuscrita da cultura trovadoresca peninsular pode ver-se em Elsa Gonçalves e Maria Ana Ramos, A Lírica Galego-Portuguesa, Lisboa, 1983, pp. 32-5.

(3) Este manuscrito encontra-se hoje na Pierpont Morgan Library, em Nova Iorque (v. Ismael Fernández de la Cuesta, "Les cantigas de amigo de Martin Codax", Cahiers de Civilisation Medieval, XXV, Poitiers, 1982, p. 179 e Manuel Pedro Ferreira, $O$ Som de Martim Codax. Scbre a dimensão musical da lírica galego-portuguesa (séculos XII-XIV), Lisboa, 1986, p. 61). Em virtude da sua nova situação passaremos a designá-lo, conforme sugestão do Professor Tavani, com a sigla $\mathrm{N}$.

(4) Para o primeiro, que passaremos a designar por A, o estudo mais completo é ainda o de Michaëlis, $C A$, em particular pp. 135-79. Para o segundo ver a recente contribuição de Manuel Pedro Ferreira, ob. cit., pp. 61-73. p. 71 e 73

(5) Tavani, Grundriss, p. 27 e 37; M. Pedro Ferreira, ob. cit.,

(6) Tavani, Grundriss, pp. 25-46, onde o autor remete para os seus trabalhos anteriores sobre o mesmo tema, iniciados em 1967. Sobre os contributos de Anna Ferrari, Elsa Gonçalves e Jean-Marie d'Heur para a discussão deste problema, ver a síntese de Elsa Gonçalves e Maria Ana Ramos, ob. cit., pp. 34-35. 
de 50 franceses e os mais de 100 italianos $\left({ }^{7}\right)$. Se estes números dizem respeito, é certo, a toda a tradição manuscrita das áreas consideradas, contemporânea ou não do fenómeno trovadoresco a que deu eco, não é menos verdade que a eles apenas poderíamos acrescentar, do lado peninsular, mais 2 cancioneiros - o da Biblioteca Nacional (B) e o da Biblioteca Vaticana (V) -, ambos copiados em Itália no séc. XVI, e duas transcrições de uma mesma composição, efectuadas na península no séc. XVII ${ }^{8}{ }^{8}$.

Esta pobreza, por um lado, a parcimónia e as dificuldades levantadas pelo carácter vago dos testemunhcs indirectos conhecidos $\left({ }^{9}\right)$, por outro, levaram a uma reorientação das investigações, no sentido de um aproveitamento mais exaustivo dos cancioneiros para a resposta ao problema da sua constituição. E pelo menos este o trajecto que se pode descortinar entre a primeira tentativa de esclarecimento da questão, efectuada por C. Michaëlis de Vasconcelos, e o novo ponto da situação, feito por G. Tavani $\left({ }^{10}\right)$. Enquanto C. Michaëlis, sem ter tido acesso

(7) Tavani, Grundriss, pp. 29-33.

(8) Quanto ao primeiro cancioneiro, que passaremos a designar por B, veja-se o estudo de Anna Ferrari, "Formazione e Struttura del Canzoniere Portoghese della Biblioteca Nazionale di Lisbona (Cod. 10991: Colocci-Brancuti)», Arquivos do Centro Cultural Português, XIV, Paris, 1979, pp. 29-139. Para o segundo, que passaremos a designar por $\mathrm{V}$, faltam estudos aprofundados. Consulte-se, no entanto, para além da obra de Tavani, Jean-Marie d'Heur "Sur la Tradition Manuscrite des Chansonniers Galiciens-Portugais», Arquivos do Centro Cultural Português, VIII, Paris, 1974, pp. 4-13 e, do mesmo autor, "Sur la généalogie des chansonniers portugais d'Ange Colocci», Boletim de Filologia, XXIX, Lisboa, 1984, pp. 23-34. As transcrições mencionadas são os dois exemplares da tenção entre Afonso Sanches e Vasco Martins de Resende, conservados na Biblioteca Nacional de Madrid (M) e na Biblioteca Municipal do Porto (P), ed. respectivamente por J. Leite de Vasconcelos, "Tenção entre D. Affonso Sanchez e Vasco Martinz", Revista Lusitana, VII, Lisboa, 1902, pp. 145-7, e C. Michaëlis de Vasconcelos, "Randglossen zum altportugiesischen Liederbuch. XV. Vasco Martinz und D. Afonso Sanchez", in Zeitschrift fur romanische Philologie, XXIX, Halle, 1905, pp. 683-711.

A estes cancioneiros e transcrições devemos acrescentar, segundo indicação do Professor Tavani, um novo cancioneiro ainda não estudado, mas que parece ser uma cópia de $\mathrm{V}$ feita em Itália nos últimos anos do séc. XVI. Tal facto, a verificar-se, tornará este cancioneiro improdutivo do ponto de vista em que nos colocamos, isto é, na perspectiva da elucidação da tradição manuscrita entre os fins do séc. XIII e meados do séc. XIV.

(9) Michaëlis, $C A$, II, pp. 232-75.

(10) Idem, ibidem, pp. 227-88. Tavani, «La tradizione manoscritta della prima lirica galego-portoghese», Cultura Neolatina, XXVII, Modena, 1967, pp. 41-94; reproduzido na obra do mesmo autor, Poesia del Duecento nella Peninsola Iberica, Roma, 1969, pp. 79-179. 
directo aos cancioneiros italianos do século XVI, se viu obrigada a privilegiar os testemunhos indirectos de que dispunha - e que entretanto não foram aumentados -, Tavani pode partir do conhecimento adquirido em relação a esses mesmos cancioneiros, controlando assim de um modo mais eficaz todas as referências coligidas por C. Michaëlis, respeitantes a presumíveis cancioneiros medievais. Baseando-se principalmente numa análise interna dos cancioneiros $\mathrm{A}, \mathrm{B}$ e $\mathrm{V}$, aos quais juntou um índice de autores portugueses feita por Colocci (C) - por a considerar como vestígio de um cancioneiro perdido -, Tavani tentou estabelecer as relações entre eles, definindo uma árvore genealógica do conjunto dos cancioneiros galego-portugueses existentes ou presumíveis e procurando situar cronologicamente as principais fases de constituição dessa tradição manuscrita ( $\left.{ }^{11}\right)$.

Para o perícdo que nos propomos abordar, dos finais do séc. XIII a meados do séc. XIV, a tradição manuscrita da cultura trovadoresca está reduzida aos elementos enunciados no início, isto é, a $\mathrm{A}$ e $\mathrm{N}$, de um lado, e ao "Livro das cantigas» do conde de Barcelos, do outro. Segundo C. Michaëlis e G. Tavani, A seria uma cópia inacabada da primeira grande compilação a qual, por sua vez, teria surgido da junção e ordenação de rolos ou folhas soltas onde trovadores e jograis escreviam ou mandavam escrever as suas composições. $\mathbf{N}$ retrataria, segundo Tavani, precisamente essa fase inicial, pré-existente à feitura dos cancioneiros propriamente ditos. A primeira grande compilação referida, albergando apenas autores do séc. XIII, teriam sido acrescentados, ainda segundo os mesmo autores, novos rolos e um ou outro cancioneiro individual - o caso de D. Dinis, por exemplo - de autores dos fins do séc. XIII e da primeira metade do séc. XIV. O «Livro das Cantigas» do conde D. Pedro não seria mais do que essa primeira compilação, ou uma sua cópia, acrescentada de novos rolos ou pequenos cancioneiros individuais pertencentes a trovadores e jograis cronologicamente posteriores à sua confecção ou, pelo menos, por ela esquecidos (12).

A elucidação do problema da tradição manuscrita entre os fins do séc. XIII e meados do séc. XIV passa, assim, por um confronto entre a grande compilação inicial e o que se supõe

(11) Tavani, ibidem, e Grundriss, pp. 25-46. Para os pontos em discussão, que nã̉o dizem respeito ao período em que nos situamos, v. Elsa Goncalves e Maria Ana Ramos, ob. cit., pp. 34-5.

(12) Michaëlis, $C A$, pp. 286-7; Tavani, Grundriss, p. 35. Não nos propomos analisar, por agora, algumas divergências entre ambos os autores sobre este período da tradição manuscrita. 
ser o «Livro das Cantigas» do conde, ou seja, segundo a parte inicial do stemma codicum proposto por Tavani,

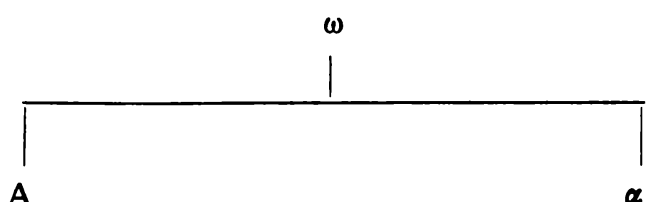

por um confronto entre $\omega$ e $\alpha$, ambos perdidos. Apesar de quer um quer outro não existirem enquanto cancioneiros autónomos, podemos fazer uma aproximação ao seu conteúdo, através dos cancioneiros existentes: utilizando para $\omega$ a sua cópia parcial A e também $\mathrm{B}$ e $\mathrm{V}$ (nas partes consideradas como reflectindo ainda o estado da compilação nos finais do séc. XIII); e, para $\alpha$, apoiando-nos apenas nos cancioneiros copiados em Itália no séc. XVI, B e V, expurgados dos acrescentos incorporados no séc. $\mathrm{XV}{ }^{(13)}$.

De $\omega a \propto$

O exame comparativo dos três cancioneiros conhecidos - A, B e V -, nas suas partes comuns, levou, desde cedo, ao reconhecimento de «notáveis concordâncias» entre eles, em virtude de composições e autores seguirem, em geral, uma ordenação idêntica em todos $\left({ }^{14}\right)$. Tal facto, sintoma da utilização de uma matriz comum, permitiria certamente inferir a estrutura dessa mesma matriz, isto é, na terminologia de Tavani, de $\omega$, enquanto arquétipo de uma tradição manuscrita de que os três cancioneiros mencionados se constituíam como elos mais salientes.

Foi Carolina Michaëlis, mais uma vez, quem fez um primeiro balanço sobre os critérios subjacentes à feitura de $\mathrm{A}, \mathrm{B}$

(13) Estes acrescentos são em número reduzido; v. lista apresentada por Giulia Lanciani, «A propósito di un testo attribuito a Fernan Velho», Estudos Italianos em Portugal, 38-39, Lisboa, 19751976, pp. 157-9.

(14) Michaëlis, CA, II, pp. 180-209. Cf. G. Tavani, Poesia del Duecento...., pp. 97-105. Ambos os autores ilustram as afinidades entre os três cancioneiros, através da apresentação de um quadro com as correspondências e divergências recíprocas. 
e $\mathrm{V}$, vestígios importantes, segundo ela, de uma «espécie de Cancioneiro Geral da primeira epoca da lyrica peninsular» $\left({ }^{15}\right)$. Apoiando-se na disposição das composições nos diversos cancioneiros e conjugando-a com os elementos de ordem biográfica dos autores aí presentes - recolhidos de várias fontes da época e, em particular, dos livros de linhagens -, concluiu que esse «Cancioneiro Geral» fora organizado tendo em conta não só os principais géneros poéticos utilizados pelos trovadores, como também a própria cronologia dos autores nela inseridos. Assim, feita a recolha de rolos e folhas contendo as composições de um ou mais autores, a obra de cada um deles teria sido distribuída pelas três secções previamente estabelecidas - a das cantigas de amor, em primeiro lugar, a das cantigas de amigo, de seguida e, finalmente, a das cantigas de escárnio e de maldizer - isto, evidentemente, apenas quando o autor em causa possuía composições dos três géneros assinalados. Feito este fraccionamento, uma segunda preocupação terá norteado, segundo a mesma autora, a acção do compilador: a de estabelecer uma certa cronologia dentro de cada seç̧ão, agrupando os autores mais antigos na parte inicial de cada uma delas e assim sucessivamente, até aos mais recentes $\left({ }^{16}\right)$. O quadro que apresentamos de seguida, confirma a organização tripartida do «Cancioneiro Geral» e permite-nos visualizar melhor o lugar nela ocupado pelos três cancioneiros que nos restam e as respectivas correspondências.

\begin{tabular}{|c|c|c|c|}
\hline & c. amor & c. amigo & c. escárnio \\
\hline A & $\ldots 1\left(^{*}\right)-310$ & - & - \\
\hline B & $1-625$ & $626-1330$ & $1330 \mathrm{~b}-1664 \ldots\left(^{*}\right)$ \\
\hline $\mathrm{V}$ & $\ldots 1\left(^{*}\right)-226$ & $227-936$ & $937-1205 \ldots\left(^{*}\right)$ \\
\hline
\end{tabular}

Sinais de uma ordenação pelos três géneros poéticos são, ainda hoje, as rubricas indicadoras do início, em $\mathrm{B}$ e $\mathrm{V}$, das seç̧ões das cantigas de amigo e das cantigas de escárnio de

(15) Michaëlis, CA, II, pp. 180 e 210.

(16) Idem, ibidem, pp. 210-4.

(*) A e V apresentam lacuna inicial. Al corresponde a B91 e V1 a B391. Em A, como sobressai do quadro, apenas foi copiada a secção das cantigas de amor. B e V apresentam, por seu lado, lacuna final. $O$ índice de trovadores portugueses de Colocci (C) regista ainda, com efeito, sob o n. ${ }^{\circ} 1675$, o início das cantigas de escárnio de Juião Bolseiro. 
ambos os cancioneiros $\left({ }^{17}\right)$. Quanto à existência de uma sequência de autores respeitadora da sua maior ou menor antiguidade no contexto da cultura trovadoresca, as indicações de C. Michaëlis de que «os que poetaram mais cedo, de 1200 a 1245 , figuram, sem excepção, no princípio do velho pergaminho, ou nas partes que lhe faltam, sendo-nos supridos por B» $\left({ }^{18}\right)$, mantêm uma quase completa actualidade $\left({ }^{19}\right)$. Referindo-se aqui apenas a $\mathrm{A}$, isto é, à secção das cantigas de amor, a autora tinha, todavia, a consciência de que uma mesma seriação existia nas restantes secções do cancioneiro a partir do qual $\mathrm{A}$ fora copiado $\left({ }^{20}\right)$.

Definida, em traços gerais, a estrutura da compilação inicial, ou seja, de $\omega$, resta sabermos se ela foi ou não mantida na totalidade dos cancioneiros aos quais temos hoje acesso. A própria C. Michaëlis se deu conta de que, quer a separação dos três géneros, quer a ordenação cronológica dos autores, não tinham sido realizadas na sua totalidade $\left({ }^{21}\right)$. Colocada, no entanto, na perspectiva de análise de $\mathrm{A}$, descurou um exame mais aturado dessas divergências e do seu alcance para a compreensão do desenvolvimento da tradição manuscrita entre os fins do séc. XIII e meados do séc. XIV $\left.{ }^{(22}\right)$. Com efeito, se A não acusa propriamente desvios às normas atrás referidas, 0 mesmo não podemos dizer de $\mathrm{B}$ e de $\mathrm{V}$. Um olhar atento às três secções de ambos os cancioneiros revela que, apesar de em boa parte delas se manterem os critérios propostos por C. Michaëlis, a partir de dada altura, na parte final de cada uma dessas secções, esses critérios deixaram de estar presentes no espírito do compilador. É esquecida não somente a divisão por géneros poéticos, incluindo-se, por exemplo, cantigas de amigo e cantigas de escárnio na secção das cantigas de amor, mas também a preocupacão por uma sequência minimamente cronológica dos autores $\left({ }^{23}\right)$.

(17) B 626 e 1330bis (Reprodução facsimilada, Lisboa, 1982, pp. 306 e 605); V 227 e 937 (Rep. facs., Lisboa, 1973, pp. 93 e 324).

(18) Michaëlis, $C A$, II, p. 222.

(19) Na parte inicial, que falta em A, é provável a existência de uma ou outra excepção resultante de acrescentos posteriores nessa zona de $\omega$.

(20) Michaëlis, CA, II, p. 212.

(21) Idem, ibidem, pp. 215-7.

(22) C. Michaëlis inicia, a partir da p. 227 da ob. cit., o exame deste problema, apoiando-se não numa análise interna dos cancioneiros, mas, como referimos, em testemunhos indirectos sobre a existência de reais ou presumíveis cancioneiros medievais.

(23) O facto de serem as zonas finais de cada secção aquelas onde esta perturbação é mais evidente, torna credível a hipótese for- 


\section{Revista de História das Ideias}

A resposta para esta viragem, para esta divergência de critérios, deve ser procurada a partir de algumas características próprias destas zonas mais conturbadas dos cancioneiros $\mathrm{B}$ e V. Ao novo ordenamento destas zonas finais de cada uma das secções, ou, se se quiser, à falta dele, correspondeu uma visão mais alargada do fenómeno trovadoresco, não só de um ponto de vista sociológico, como também de um ponto de vista geográfico. Concretizando, o tom aristocrático anterior da compilação foi complementado, nestas zonas - e tanto quanto o podemos saber pelos elementos biográficos conhecidos - , pela integração de jograis e clérigos e também pela inclusão de obras régias. A este alargamento do quadro sociológico dos autores presentes nos cancioneiros, acrescente-se uma melhor definição da geografia trovadoresca, através da incorporação de um grupo de novos autores cuja naturalidade tem sido situada na Galiza $\left({ }^{24}\right)$. Um último elemento a tomar em consideração é a cronologia dos autores aqui presentes. Ao contrário de $\omega$, onde dominam claramente os trovadores dos primeiros três quartéis do séc. XIII $\left({ }^{25}\right)$, nestas zonas vamos encontrar muitos autores dos finais do séc. XIII e da primeira metade do séc. XIV ${ }^{(26)}$. Este conjunto de novidades, por comparação com os critérios de $\omega$, obriga-nos a pensar que nos confrontamos, sem dúvida, com um novo compilador, cuja mentalidade, forjada pela consciência da degradação da manifestação cultural que pretendia resguardar, se afasta já nitidamente da que havia presidido à compilação de $\omega$. $\mathrm{Na}$ verdade, ao espírito de selecção e organizaçãc visíveis neste, sobrepõe-se agora a urgência de tudo preservar, sentindo-se mesmo a necessidade de justificar, em casos mais imprevisíveis, a respectiva inclusão $\left({ }^{\mathbf{2 7}}\right)$.

mulada por C. Michaëlis, ob. cit., p. 211, de que "cada uma das tres Partes formasse originariamente um grosso in-folio separado, e que somente nas cópias cartaceas as juntassem, reduzindo o volume por omissão das musicas e por substituição da letra de codices pelo cursivon.

(24) Para os autores da zona final da secção das cantigas de amigo, a mais extensa e aquela onde estas características são mais visiveis, v. as fichas biográficas que juntamos em apêndice.

(25) Michaëlis, $C A$, II, p. 222.

(28) Aos autores que constam das fichas biográficas do apêndice, podemos acrescentar D. Afonso XI, Caldeiron, D. Dinis, Estêvão Fernandes Barreto, Estêvão da Guarda, Fernão Rodrigues Redondo, João Romeu de Lugo, João Velho de Pedregais, o conde D. Pedro e ainda Vidal.

(27) As duas cantigas de amor de Vidal, judeu de Elvas, colocadas na zona final da secção das cantigas de escárnio, são antecedidas pela seguinte rubrica, "Estas duas cantigas fez hû judeu d'Elvas que avia nome Vidal por amor dûa judia de ssa vila que avia nome 
Podendo admitir-se, à partida, a intervenção de um ou mais compiladores na fase final das três secções do cancioneiro, estes acrescentos a $\omega$ teriam sido efectuados, de qualquer modo, já no séc. XIV e, pelo menos em alguns casos, por volta de meados do século $\left({ }^{28}\right)$. Por outras palavras, situámo-nos precisamente no nível $\alpha$ de Tavani, associado, desde cedo, ao "Livro das Cantigas» do conde D. Pedro $\left({ }^{29}\right)$.

Ao deixarem ainda bem visíveis as marcas de duas grandes intervenções no seu seio, B e V transformam-se, assim, em palco privilegiado, e provavelmente único, para ajuizarmos da evolução da tradição manuscrita no período em análise. A partir dessas marcas pudemos assinalar a existência dos níveis (1) $\mathrm{e} \alpha$, incorporados por ambos os cancioneiros. Procuraremos agora, também com a ajuda de $\mathrm{A}$, acercarmo-nos mais desses dois níveis, tentando definir a zona de intersecção entre eles.

Conhecidos os critérios subjacentes à compilação de $\omega$, verificamos a sua manutenção na seç̧ão das cantigas de amor até ao último autor presente em A, Rui Fernandes de Santiago $\left({ }^{30}\right)$, na secção das cantigas de amigo até às duas cantigas

Dona. E pero que é ben que o ben que home faz se non perca mandamolo screver; e non sabemos mais delas mais de duas cobras, a primeira cobra de cada hûa». Cf. Luciana Stegagno Picchio, "As cantigas de amor de Vidal judeu de Elvas», na obra da mesma autora, $A$ Lição do Texto. Filologia e literatura. I-Idade Média, Lisboa, 1979, pp. 69-71.

(28) Registe-se a presença, nestas zonas, de D. Afonso XI, D. Dinis, Estevão da Guarda, Fernão Rodrigues Redondo, João, jogral de Leão, D. João Mendes de Briteiros, Martim Peres Alvim e do conde D. Pedro, todos vivos nos inícios da década de 20 do séc. XIV e, alguns deles, ainda em meados do mesmo século.

(29) Ver G. Tavani, Poesia del Duecento..., pp. 136-7, e L.F. Lindley Cintra, $o b$. cit., pp. XIV-XV.

(30) A 308-310 (Michaëlis, CA, I, pp. 619-23). Este cancioneiro apresenta, na sua parte final, divergências em relação a $B$ e a $V$ (v. primeira coluna do quadro com a zona de intersecção entre $\omega$ e $\alpha$, em apêndice). Solaz, Padrom, Ponte, Calvelo, Moya e Rui Fernandes, os últimos autores de $\mathbf{A}$, faltam nas zonas respectivas de $\mathbf{B}$ e V, comparecendo, no entanto, na secção das cantigas de amigo de ambos os cancioneiros, mas já na sua zona conturbada, isto é, no nível $\alpha$, com inclusão parcial ou total das cantigas de amor presentes em A. Segundo C. Michaëlis, $C A$, II, pp. 217-8, a ordenação primitiva é a de A, tendo-se dado posteriormente um deslocamento dessas composições para a secção das cantigas de amigo. G. Tavani, Poesia del Duecento...., pp. 145-50 , e Jean-Marie d'Heur, "Nomenclature des Troubadours Galiciens-Portugais (XIIe-XIVe siècles)", Arquivos do Centro Cultural Português, VII, Paris, 1973, p. 73, privilegiaram, como mais correcta, a colocação destes autores na secção das cantigas de amigo. No entanto, a inserção das cantigas de amigo de Solaz, Ponte e Calvelo na respectiva secção, ria parte final da zona em gue ainda se observam os critérios ordenadores de $\omega$, confirmam a interpretação de C. Michaëlis (na seounda coluna do quadro, em apêndice, pode ver-se a colocação de Pedr'Eanes 
do mesmo género de Vasco Rodrigues de Calvelo ( ${ }^{31}$ ) e, na secção das cantigas de escánio e de maldizer, até às treze cantigas de escárnio de Afons' Eanes do Coton $\left({ }^{32}\right)$. Pondo de parte algumas fugas às normas mencionadas para estas zonas do cancioneiro, que interpretamos como sinais do seu manuseio posterior e não analisaremos neste momento, estamos perante aquilo que seria $\omega$ no momento da sua compilação. Até cerca de meados do séc. XIV nele, ou numa sua cópia, foram inseridas, ressalvando os já aludidos acrescentos do séc. XV e, eventualmente, algumas deslocações de autores já incorpcrados, as restantes composições. Assim, a primeira seç̧ão teria recebido as composições que surgem, apenas em $\mathrm{B}$ e $\mathrm{V}$, na sequência das de Rui Fernandes $\left({ }^{33}\right)$; a segunda, as que se seguem às de Vasco Rodrigues $\left({ }^{34}\right)$; e a última secção, as que completam o cancioneiro após as treze de Afons' Eanes ${ }^{\left({ }^{35}\right.}$ ).

A definição desta zona de intersecção entre $\omega$ e $\alpha$ somente pôde ser feita após um cuidadoso exame da colocação dos autores nos cancioneiros $\mathrm{A}, \mathrm{B}$ e V, combinado com a sua cronologia, o tipo de composições com que aparecem nessa zona, a sua naturalidade e a sua condição social. Exemplificando com os autores que pensamas terem sido incorporados nos cancioneiros numa fase posterior a $\omega$, os que se seguem a Rui Fernandes

Solaz, Pero da Ponte e Vasco Rodrigues nessa zona. Apesar deste novo enquadramento, esta questão, não fica, porém, completamente esclarecida. Como se depreenderá do exame da colocação destes autores, feito na sequência deste estudı, se a hipótese do seu deslocamento é a mais credível, ficam ainda por solucionar os problemas resultantes da não correspondência entre o número das composições presentes em A, por um lado, e em BV, por outro, e também do estado das composições em ambos os cancioneiros (v. ficha de Pedr'Eanes Solaz). Embora a possibilidade da existência de uma outra tradição manuscrita, pelo menos para três desses autores, possa iustificar algumas das discrepâncias verificadas, podem, no entanto, ter intervido outros factores. Estamos, seguramente, perante a zona mais conturbada dos cancioneiros, merecedora, por si só, de um estudo atento e aturado, cujas conclusões poderiam ser da maior importância para precisar o modo como $\omega, \mathrm{A}$ e BV se relacionaram entre si.

(31) B 850-851 (ed. cit., pp. 388-9), V 436-437 (ed. cit., pp. 166-7). Note-se que este autor é o antepenúltimo de A.

(32) B 1579-1591 (pp. 704-708), V 1111-1123 (pp. 393-7).

(33) B 454-625 (pp. 225-306), V 61-226 (pp. 37-93). V é lacunar no início deste acrescento.

(34) B 852-1330 (pp. 389-605), V 438-936 (pp. 167-324).

(35) B 1592-1664 (pp. 708-752), V 1124-1205 (pp. 397-427). Da sua ccmparacção com o índice de autores portugueses de Colocci (C), deduz-se que a parte final de ambos os cancioneiros está incompleta (v. Elsa Gonçalves, "La Tavola Colocciana, Autori portughesi», Arquivos do Centro Cultural Português, X, Paris, 1976, pp. 433 e 448). 
na primeira secção afastam-se dessa mesma compilação pelo tipo de composições aí inseridas, bem como pela sua cronologia. $\mathrm{Na}$ secção das cantigas de amigo, e exceptuando o caso de Mendinho, a situação é idêntica, embora coloque outros problemas $\left({ }^{36}\right)$. Na última secção, onde os primeiros autores do acrescento obedecem à organização de $\omega$, isto é, comparecem apenas com cantigas de escárnio, a sua colocação no nível $\alpha$ resulta do facto de, ausentes das anteriores secções de $\omega$, aparecerem apenas nos grupos de autores acrescentados à secção das cantigas de amigo desse cancioneiro. $\mathrm{O}$ caso de Diego Pezelho, presente somente na última secção, é o mais duvidoso. Incluímo-lo nos autores de $\alpha$ em virtude da sua condição de jogral. As conclusões deste trabalho poderão tornar mais aceitável esta opção.

\section{C acrescento à secção das cantigas de amigo de $\omega$}

Se os novos autores acrescentados às primeira e terceira secções, pelo seu reduzido número, não levantam grandes problemas, o mesmo não se poderá dizer daqueles que dão sequência à secção das cantigas de amigo. Com efeito, ao contrário do que acontecera nas restantes secções, aqui o número de novos autores é significativamente maior do que os já existentes nessa secção em $\omega$. Aos 45 autores aí incluídos ( ${ }^{37}$ ), somam-se agora mais 67, numa numeração que vai de 1 a $79\left({ }^{(38}\right)$, o que significa que alguns deles nos aparecem mais de uma vez. Esta anomalia adquire maior relevo quando começamos a verificar a dominância da presença galega neste amplo grupo de autores. De facto, os trovadores portugueses, impondo-se claramente aos restantes nas outras zonas do cancioneiro, surgem aqui mais espaçadamente, isolados ou em pequenos grupos de dois ou de três $\left({ }^{39}\right)$.

Tavani, nos seus estudos sobre a tradição manuscrita da lírica galego-portuguesa, chamara já a atenção, desde 1967, para dois elementos, de certo modo estranhos, presentes nesta zona

(36) Vejam-se as fichas individuais dos autores deste acrescento, em apêndice, e, na parte em que analisamos a sua estratigrafia, as dúvidas suscitadas pela colocação de Mendinho.

$\left.{ }^{37}\right)$ Este número não toma em consideração os possíveis acrescentos verificados nesta secção de $\omega$ a partir de fins do séc. XIII.

(38) V., em apêndice, o quadro da colocação dos autores deste acrescento.

(39) V., em apêndice, os dados biográficos reunidos para cada um dos autores em análise. 


\section{Revista de História das Ideias}

da seç̧ão das cantigas de amigo $\left({ }^{40}\right)$. O primeiro, a presença ce um grupo de clérigos todos reunidos na parte inicial desta zona, entre os $n .^{\circ s} 5$ e 17. A sua relativa autonomia em relação ao cancioneiro era ditada não só pela pertença ao mesmo estrato social como pelo completo desrespeito em relação à organização inicial do cancioneiro nos três grandes géneros poéticos. Inseridos na secção das cantigas de amigo, aí se encontrava reunida toda a sua obra, englobando não apenas cantigas de amigo, mas também cantigas de amor, cantigas de escárnio e de maldizer, prantos, etc. O segundo elemento estranho era, segundo o mesmo autor, a rubrica que antecedia as cantigas de amor de Bernal de Bonaval (.$\left.^{\circ} 30\right)$ : «En esta folha adeante se comenzam as cantigas d'amor. Primeyro trobador: Bernal de Bonavalle» ( $\left.{ }^{41}\right)$. Elemento estranho não tanto pela sua existência em si - no início das secções das cantigas de amigo e das cantigas de escámio e de maldizer há rubricas idênticas -, mas pelo lugar e contex to em que nos surge: no meio da secção das cantigas de amigo e encimando as cantigas de amor do referido autor e de alguns mais que o seguem (n.os 30 a 43). Partindo destes dados, Tavani concluía tratar-se, em ambos os casos, de indícios de "recolhas parciais de tipo diverso» que, tal como os rolos ou folhas volantes e os cancioneiros individuais atrás mencionados, teriam sido sucessivamente integrados no arquétipo de A. E ia mesmo mais longe: «In linea teorica non é impossibile che l'archetipo della tradizione canzonieresca non sia stata né la prima né la sola antologia organizzata secondo lo stesso principio della divisione per generi: molti dei rotuli individuali ipoteticamente riconoscibili nella tradizione e lo stesso 'Liederbuch' di D. Denis rivelano un'organizzazione analoga; ma, accanto a questi esempi, é possibile congetturare l'esistenza di sillogi minori che avrebbero raccolto i testi di poeti lasciati fuori dalla silloge maggiore per i motivi cronologici, pratici o estetici, ai quali si è accennato" $\left({ }^{42}\right)$.

A dimensão do acrescento à secção das cantigas de amigo de $\omega$, o número de autores galegos aí presentes, as novas formas de ordenação de autores e composições aí detectadas e, finalmente, o indício claro de existência de uma outra compilação, dado pela rubrica que antecede as cantigas de amor de Bernal de Bonaval, transformam este acrescento num caso singular de dúvidas e perplexidades. Dada a importância da resolução dos problemas que levanta, orientaremos para ele, a partir de agora, a nossa atenção.

(40) Cf. Tavani, Grundriss, pp. 41-2.

(41) Antes de B 1062 (p. 486) e de V 653 (p. 235).

(42) Tavani, Grundriss, p. 41. 
A primeira observação que se poderá, desde logo, fazer é a de que o compilador de meados do séc. XIV não se terá limitado a incorporar aí, e de um modo mais ou menos anárquico, apenas pequenos rolos ou cancioneiros individuais de autores ausentes de $\omega$ mas, pelo contrário, terá tido acesso a compilações mais alargadas e, elemento não menos importante, feitas com um espírito diferente daquele que tinha presidido à elaboração da primeira grande compilação (veja-se, por exemplo, o grupo de clérigos situado na parte inicial deste acrescento). A segunda e última observação prende-se com a força da presença galega neste mesmo acrescento. Uma excepção, como vimos, se tivermos em conta o resto do cancioneiro. A primeira vista pode pensar-se que, com este compilador, confluíram no cancioneiro português tradições manuscritas cujo. trajecto anterior teria sido não só independente da compilação portuguesa, mas também exterior ao próprio espaço português e aos círculos cortesãos frequentados pelos seus trovadores.

A resolução destas observações e hipóteses passa, naturalmente, por uma análise mais atenta do conjunto dos autores que constituem o acrescento cuja formação nos propomos elucidar. Para tal, partimos de uma investigação individual levada a cabo sobre cada um desses autores, onde pusemos em confronto, no fundamental, os elementos utilizados já na definição da zona de intersecção de $\omega \operatorname{com} \alpha$, ou seja: sua colocação, tipo de composições, cronologia, naturalidade e condição social $\left({ }^{43}\right)$. A escolha desta grelha foi ditada pelos objectivos que pretendemos alcançar: o esclarecimento dos diversos grupos ou estratos inseridos neste acrescento, a sequência e cronologia prováveis da sua incorporação, o seu grau de coerência e autonomia previamente a essa incorporação e, finalmente, a cronologia provável da sua junção ou compilação, nos casos em que isso se possa ter verificado. Objectivos a que será difícil não reconhecer importância no contexto da evolução da tradição manuscrita entre os fins do séc. XIII e meados do séc. XIV. Uma aproximação mais exacta à cronologia de vários autores menos conhecidos surgirá por acréscimo. As conclusões que tirarmos poderão, finalmente, propor um novo enquadramento

(43) As fichas individuais resultantes dessa investigação foram divididas em dois blocos. No primeiro, discutimos todos os problemas levantados pela colocação do autor em análise; no segundo, traçamos uma rápida biografia desse mesmo autor. $\mathrm{Na}$ economia do trabalho, estas fichas deveriam anteceder o exame da estratigrafia deste acrescento. Dado, no entanto, o seu carácter probatório e no sentido de não quebrarmos a sequência da exposição, remetemos esses elementos para um dos apêndices deste estudo. 
para a resolução das muitas dificuldades levantadas pelo estado em que nos chegaram as composições trovadorescas: as atribuições de uma mesma cantiga a dois autores diferentes ou a sua repetição na obra de um mesmo autor, as indicações de existência de rolos, a presença das mesmas composições em dois lugares diferentes dos cancioneiros, etc., etc.

O método utilizado não é novo. Limitámo-nos a seguir o caminho aberto por C. Michaëlis na análise das relações entre A, B e V ( $\left.{ }^{44}\right)$, ampliando um pouco os elementos por ela manejados e aplicando-os ao esclarecimento da tradição manuscrita. Pudemos também beneficiar de uma certa efervescência verificada, durante as últimas duas décadas, no estudo da lírica galego-portuguesa, cujo resultado se cifrou, indubitavelmente, num conhecimento mais profundo dos cancioneiros medievais. Da nossa parte, contribuimos com o olhar do historiador, protegido por uma informação mais completa sobre os trovadores, em particular os portugueses. Daí termos destacado, na separação dos vários estratos do acrescento, os critérios da naturalidade e da condição social. Com excepção dos acrescentos pós-trovadorescos, já conhecidos, pareceram-nos os mais indicados para podermos reconstituir os grupos aí existentes. A escolha não foi, portanto, arbitrária. Por outro lado, como acentuamos, dada a ausência da organização de $\omega$ neste e nos outrcs acrescentos, a utilização dos critérios da colocação e do tipo de composições não seria adequada a essa reconstituição. No entanto, uma vez separados esses grupos, a sua análise interna não pôde prescindir de ambos os critérios bem como da cronologia dos autores aí presentes. Desta última, no sentido de propormos uma datação para a constituição desses grupos e para a sua incorporação em $\omega$; daqueles, no intuito de aquilatarmos da consistência interna desses mesmos grupos.

Ao longo da seriação individual - em apêndice - foram sendo anotadas afinidades, de tipo diverso, entre vários autores. Serão elas que nos conduzirão agora a uma definição mais detalhada e sistemática de cada um desses conjuntos de autores tomados isoladamente. Optamos por uma inventariação feita a partir do estado deste acrescento nos inícios do séc. XVI, data em que o cancioneiro português é copiado em Itália. Permitir-nos-á visualizar melhor, embora em sentido inverso, a progressiva formação do núcleo de autores em estudo.

(44) Michaëlis, CA, II, pp. 180-226. 


\section{Acrescentos pós-trovadorescos $(*)$}

(19) Anónimo

(32) Diogo Gonçalves de Montemor-o-Novo

(34) Anónimo

(53) Anónimo

Somente a partir de meados da década de sessenta, graças aos estudos da crítica italiana e, em particular, de G. Tavani, começaram a ser exumados dos cancioneiros $\mathrm{B}$ e $\mathrm{V}$ um conjunto de textos, até então considerados como pertencentes à lírica galego-portuguesa medieval, mas cuja análise revelou tratar-se de interpolações tardias, efectuadas ao longo do séc. XV no ou nos cancioneiros medievais anteriores $\left({ }^{45}\right)$. Alheios à tradição poética da cultura trovadoresca peninsular, interessam menos à elucidação do problema da constituição do cancioneiro até meados do séc. XIV do que ao conhecimento do seu estado no período posterior.

Alguns desses textos foram incluídos no acrescento em análise. Estamos, em todos os casos, perante intervenções de pouca importância, limitando-se a preencher alguns espaços deixados em branco no cancioneiro ${ }^{\left({ }^{48}\right)}$. Daí uma distribuição de certo modo aleatória. Dois deles (n. ${ }^{\text {os }} 19$ e 53) terão aproveitado, no entanto, zonas do cancioneiro já perturbadas por arranjos anteriores.

\section{Os trovadores portugueses}

(2) Afonso Pais de Braga

(3) D. Mem Rodrigues de Briteiros

(4) D. João Mendes de Briteiros

(10) Pero Gonçalves de Portocarreiro

(11) Pero Goterres

(12) D. Estevão Peres Froião

(*) Quando a sequência dos autores, nas listas que se seguem, não corresponde à sequência desses mesmos autores nos cancioneiros, optamos por separá-los a dois espaços. Quando, pelo contrário, essa sequência reproduz a dos cancioneiros, utilizamos apenas um espaço. Nos casos em que a presença de um autor nos cancioneiros está dependente da obra de outro, mantivemos a numeração da obra deste último acrescida do número 2 .

(45) Ver Givlia Lanciani, ob. cit., pp. 157-9.

(46) Anna Ferrari, ob. cit., p. 128. 
? (20) Airas Engeitado

(21) Rodrigu' Eanes d'Alvares

(25) Rui Martins d'Oliveira

(26) D. Pero Gomes Barroso

(28) Martim Peres Alvim

(36) Estevão Fernandes d'Elvas

(44) João, jogral de Leão

(46) Pero Mendes da Fonseca

(51) João Zorro

(52) Rui Martins do Casal

(76) Fernand' Esquio

(77) Estevão da Guarda

(78) João Fernandes d'Ardeleiro

(79) D. Mem Rodrigues de Briteiros

Apesar do título, nem todos os trovadores são portugueses. A inclusão de Airas Engeitado, sobre o qual nada se sabe de concreto, neste grupo é feita mais pela negativa, isto é, pelo facto de nada o ligar aos grupos ou autores que serão analisados posteriormente. Note-se, no entanto, a sua associação ao trovador português Rodrigu'Eanes d'Alvares, entre as composições de João Airas de Santiago e as de alguns autores deslocados de $\mathrm{A}$ (n. ${ }^{\text {os }}$ 22-24), numa situação igual à de Rui Martins d'Oliveira e de D. Pero Gomes Barroso, ambos também trovadores portugueses. Quanto às restantes excepções, o jogral João e Fernand'Esquio, apenas o são em virtude da sua naturalidade e não em termos de colocação. A presença do primeiro $\epsilon m_{1}$ Portugal, na primeira metade do séc. XIV, justifica um tipo de colocação idêntica à dos restantes autores portugueses. Pode ter sucedido o mesmo ao segundo, embora nos faltem elementos comprovativos. De qualquer modo, a junção das suas cantigas de amor e de amigo afasta-os dos autores que o antecedem, também galegos, mas pertencentes cerfamente a um estrato social inferior ao seu.

A colocação deste grupo de trovadores portugueses numa fase já avançada da formação deste acrescento, é-nos ditada por uma situação pouco homogénea, não só do ponto de vista da sua inserção - 20 autores em 10 lugares diferentes deste acrescento -, como também do género, muito diversificado, das composições que constituem a sua obra. Olhando o quadro geral 
nota-se, além disso, que a sua inclusão, parecendo um tanto aleatória, obedeceu já, com poucas excepções, a uma estrutura pré-existente.

Concretizando, o primeiro subgrupo de autores (15 compcsições) inicia praticamente este acrescento, imediatamente antes do conjunto de clérigos aí presente. $O$ segundo $(7 \mathrm{com}$ posições) aparece integrado neste conjunto de clérigos, mas próximo duma zona que teria sido previamente reformulada com a inclusão de autores de A (n. $\left..^{o s} 7-8\right)$. Os dois subgrupos seguintes ( 4 e 5 composições, respectivamente), surgem numa zona igualmente reformulada pela inserção de novos autores de A (n. ${ }^{\circ 2}$ 22-24), e entre as cantigas de amor e as cantigas de amigo de João Airas de Santiago. Martim Peres Alvim (7 composições), isolado, segue-se a João Airas e precede um grupo de autores relativamente homogéneo, onde se verifica uma separação nítida entre cantigas de amor e cantigas de amigo. O jogral João (2 composições) e Pero Mendes da Fonseca (5 composições), separados por Pedro de Berdia, separam, por sua vez, as cantigas de amor das cantigas de amigo desse grupo. O último subgrupo (38 composições), encabeçado por Fernand' Esquio, finaliza este acrescento, imediatamente antes da secção das cantigas de escárnio e de maldizer. Somente Estevão Fernandes d'Elvas (3 composições) e o subgrupo constituído por João Zorro e Rui Martins Casal (17 composições), quebraram, a sequência de cantigas de amor e cantigas de amigo deste acrescento. Concluindo, a colocação dos trovadores portugueses parece ter obedecido a uma ocupação dos pontos mais frágeis duma cadeia sequencial anterior, em locais que não punham em causa a homogeneidade dos diversos grupos aí inseridos, ou, quando o fizeram, em virtude de novos acrescentos entretanto aí verificados.

A cronologia da obra destes trovadores, activos principalmente nos fins do séc. XIII e na primeira metade do séc. XIV, remete para uma inclusão efectuada talvez no segundo quartel deste século, sendo de admitir a hipótese de, num ou noutro caso, ela poder ter-se dado um pouco depois (veja-se, por exemplo, Estevão da Guarda cuja morte, como referimos na respectiva ficha, ocorreu já na década de sessenta deste século).

Pertencendo, na sua maioria, a uma nobreza secundária ou mesmo obscura que cumpria certamente funções de ordem vassálica junto de casas senhoriais mais importantes, a recolha das suas composições poderá ter sido mais morosa do que a de alguns trovadores ligados à corte régia. 


\section{Autores com cantigas de amor de $A$}

(7) Martim Moya (*)

( 8) Rui Fernandes de Santiago

? (19) Afons'Eanes

(22) Fernão Padrom

(23) Pero da Ponte

(24) Vasco Rodrigues de Calvelo

(61) Pedr' Eanes Solaz

Deste grupo de 7 autores, 6 estão unidos por uma mesma presença no final de A e pelo deslocamento das suas cantigas de amor desse cancioneiro, no todo ou em parte, para este acrescento à secção das cantigas de amigo de $\omega$. A única excepção é Afons' Eanes (do Coton), para o qual aventamos a hipótese de ser um dos autores anónimos de A (v. respectiva ficha).

Ao contrário da sua situação em A, estes autores aparecem um tanto dispersos neste acrescento: Martim Moya e Rui Fernandes no grupo dos clérigos; Fernão Padrom, Pero da Ponte e Vasco Rodrigues, com alguns trovadores portugueses, entre as composições de João Airas de Santiago; Pedr'Eanes Solaz, finalmente, no meio de um grupo de autores apenas com cantigas de amigo, numa zona já avançada deste acrescento. Compare-se, no entanto, a sequência de $\mathrm{A}$ com a ordem em que surgem neste acrescento:

A

B e V

\begin{tabular}{|l|l|}
\hline $\begin{array}{l}\text { Pedr' Eanes Solaz } \\
\text { Fernão Padrom }\end{array}$ & $\begin{array}{l}\text { Martim Moya } \\
\text { Rero da Ponte Fernandes de Santiago }\end{array}$ \\
$\begin{array}{l}\text { Vasco Rodrigues de C. } \\
\text { Martim Moya } \\
\text { Rui Fernandes de S. }\end{array}$ & $\begin{array}{l}\text { Fernão Padrom } \\
\text { Pero da Ponte }\end{array}$ \\
\hline
\end{tabular}

Martim Moya e Rui Fernandes, os últimos autores de A, são os primeiros a comparecer nesta secção. Seguem-se os três anteriores de A, novamente juntos e pela mesma ordem. Pedr' Eanes Solaz, o primeiro deste grupo em A, é o último deles

$\left(^{*}\right)$ Sobre o nome deste autor, ver a ficha biográfica respectiva, em apêndice. 
nesta secção, bastante afastado já dos três anteriores. Perante esta inversão, em três grupos, da ordem de A, é de admitir um deslocamento por fases, contemporâneo ou já posterior à inclusão dos principais núcleos deste acrescento, que serão analisados na sequência deste trabalho. Embora para três destes autores se possa pôr a hipótese da existência de duas tradições manuscritas diferentes (v. fichas de Martim Moya, de Pedr' Eanes Solaz e de Rui Fernandes), o mais natural é ter-se verificado um deslocamento de cantigas de amor da respectiva secção de $\omega$ para 0 acrescento em análise, na altura em que um conjunto de novos autores, na sua maioria portugueses, foram acrescentados à secção das cantigas de amor desse cancioneiro.

Se a nossa hipótese é correcta, isto é, se essa transferência se ficou a dever aos novos autores acrescentados à secção das cantigas de amor de $\omega$, poderá pensar-se numa inserção feita no segundo quartel do séc. XIV, contemporânea ou talvez um pouco anterior à dos autores portugueses presentes neste acrescento.

4. O cancioneiro galego

(29) Pero de Ver

(30) Bernal de Bonaval

(30/2) Abril Peres

(31) João Servando

(33) Juião Bolseiro

(35) Pero d'Armea

(37) Pedr' Amigo de Sevilha

(38) Airas Pais

(39) Lourenço

(40) João Baveca

(41) Galisteu Fernandes

(42) Lopo

(43) Lourenço

(45) Pero de Berdia

(47) Nuno Porco

(48) Pero de Ver

(49) Bernal de Bonaval

(50) João Servando

c. amigo

c. amor

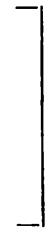


(54) Juião Bolseiro

(55) Martim Campina

(56) Pero Meogo

(57) Martim de Caldas

(58) Nuno Trez

(59) Pero d'Armea

(60) Pedr' Amigo de Sevilha

(62) João Baveca

(63) Pero de Ambroa

(64) Pai Calvo

(65) Martim Padrozelos

c. amigo (cont.)

(66) Lopo

(67) Galisteu Fernandes

(68) Lourenço

(69) Golparro

(70) João de Cangas

(71) Martim de Ginzo

(72) Martim Codax

(73) Airas Pais

(74) Fernão do Lago

(75) João de Requeixo

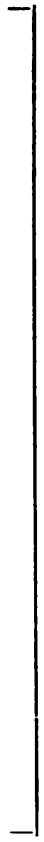

A junção deste vasto grupo impõe-se pelas características particulares da sua colocação. Com efeito, ao contrário do carácter um tanto anárquico da inserção dos grupos de autores anteriormente referidos, nota-se desde logo, neste conjunto de autores, uma organização prévia à sua inclusão neste acrescento. Assim, aparecem-nos primeiro as cantigas de amor (n. ${ }^{\circ 8}$ 29-43), depois as cantigas de amigo ( $\left({ }^{\circ}{ }^{\text {s }} 45-75\right)$ e finalmente as cantigas de escánio e de maldizer, mas estas integradas no acrescento da respectiva secção ou mesmo no contexto da organização inicial dessa secção em $\omega$ (v. fichas de João Servando, Lourenço, João Baveca e Pero de Ambroa). Todos os autores com cantigas de amor reaparecem de seguida, com cantigas de amigo, no respectivo núcleo, boa parte deles pela mesma ordem, e, a maioria, são incorporados também na seç̧ão das cantigas de escárnio e de maldizer com igual tipo de composições.

Diante destes elementos não temos dúvidas em afirmar estarmos perante um cancioneiro galego-português, integrado posteriormente no arquétipo de $\mathrm{A}$, mas deixando ainda bem visíveis as marcas da sua organização anterior. Uma organização que se aproximava, aliás, da existente em $\omega$, no que dizia respeito à divisão em três partes, em virtude dos três géneros poéticos mais utilizados pelos trovadores. Deste cancioneiro, $\mathrm{B}$ e $\mathrm{V}$ conservaram ainda a rubrica com que se iniciavam as 
suas cantigas de amor (v. ficha de Bernal de Bonaval); uma rubrica, note-se, bastante semelhante às que encimavam as secções das cantigas de amigo e das cantigas de escárnio e de maldizer de $\omega$.

A sua ordenação actual não deve ser, no entanto, a original. Para além dos rearranjos posteriores a que deve ter sido submetido, quando da integração de outros autores no seu seio, principalmente portugueses como vimos, é natural que outras perturbações tenham ocorrido no momento da sua inserção neste acrescento. $\mathrm{O}$ deslocamento das suas cantigas de escárnio já foi assinalado. A presença das cantigas de amor de Nuno Porco e de Pero de Ambroa, uma em cada caso, junto das cantigas d $\epsilon$ amor de $\omega$, revela outro deslocamento, o qual deve ter-se verificado nesta altura, ou mesmo depois. Assinale-se, finalmente, o facto das cantigas de amor de Pero de Ver, autor que antecede Bernal de Bonaval no núcleo das cantigas de amor e também das de amigo, precederem a rubrica indicadora do início das cantigas de amor deste cancioneiro. Para esta anomalia não encontramos, de momento, outra justificação a não ser a possibilidade de este cancioneiro, mesmo antes de ser incorporado neste acrescento, poder ter sido alterado também pela inclusão de um ou mais autores.

Para além da colocação, um segundo elemento parece unir este conjunto de autores: a sua naturalidade galega. A partir do nome, das referências das suas composições, das ligações a outros autores galegos, tal naturalidade tem sido atribuída a Airas Pais, Bernal de Bonaval Golparro, João Baveca, João de Cangas, João de Requeixo, João Servando, Lopo, Pero d'Armea, Pero de Berdia, e Pero Meogo $\left({ }^{47}\right)$. Em relação aos restantes, as dúvidas têm sido maiores. Quanto a Abril Peres (incluído na obra de Bernal de Bonaval), Fernão do Lago, Juião Bolseiro, Martim de Caldas, Martim Campina, Martim de Ginzo, Martim de Padrozelos, Pai Calvo e Pero de Ver, a crítica tem manifestado mais reticências, ou tem-se dividido entre uma naturalidade galega ou portuguesa. Finalmente, para um terceiro grupo, constituído por Galisteu Fernandes, Lourenço e Nuno Porco, as atribuições, sem argumentos que se possam considerar completamente seguros, têm-se inclinado mais para Leão, no primeiro caso, e para Portugal, nos dois restantes.

Perante os elementos de carácter biográfico disponíveis (e que apresentamos em apêndice) e conjugando-os agora com o facto de aqui nos aparecerem como um bloco dotado de certa

(47) Ver fichas biográficas individuais, em apêndice. Não encontramos, para qualquer deles, elementos biográficos seguros que pudessem por em causa a naturalidade que lhes tem sido atribuída. 
coerência, reforça-se, a nosso ver, a possibilidade de estarmos perante um cancioneiro contendo maioritária ou mesmo exclusivamente autores galegos. No mínimo, os casos mais duvidosos devem ser repensados neste novo contexto. Com efeito, reforçando, em nosso entender, a naturalidade atribuída aos autores do grupo já provadamente galego, esta análise leva-nos, desde já, a admitir como provável uma mesma naturalidade para os dois grupos ainda duvidosos. Lembremos que nos casos de Fernão do Lago, Martim Caldas, Martim Campina, Martim de Ginzo, Martim Padrozelos e Pero de Ver, o apelido de todos eles é também topónimo galego. Quanto a Abril Peres, Juião Bolseiro, Pai Calvo, Galisteu Fernandes, Lourenço e Nuno Porco, teremos de verificar para cada um deles, a partir da nova hipótese, a sua naturalidade galega.

Este último grupo de autores, pelas dificuldades que ainda levanta, merece-nos uma atenção particular. Não desconhecemos que, em relação a Abril Peres, a sua estadia em Portugal é incómoda para o ponto de vista adoptado $\left.{ }^{48}\right)$. Note-se, no entanto, que somente a sua consideração como jogral galego resolveria de um modo aceitável as dificuldades resultantes quer da sua colocação no cancioneiro, dependente da do segrel galego Bernal de Bonaval, quer do facto, registado como paradoxal, da sua presença em Lisboa na fase inicial desta manifestação cultural. Para justificarmos esta presença basta pensarmos na hipótese, bastante plausível, de nos encontrarmos perante um jogral trazido da Galiza por D. Gonçalo Mendes de Sousa e pelo seu irmão, o trovador D. Garcia Mendes d'Eixo, ambos ausentes de Portugal durante parte da segunda década do séc. XIII ( ${ }^{(99)}$. Quanto aos restantes, teremos que aguardar por elementos mais seguros. Pensamos, no entanto, para Galisteu Fernandes e Nuno Porco, que a hipótese galega é só por si mais verosímil do que a de C. Michaëlis, quando os considerou ao primeiro leonês e ao segundo português. Finalmente, em relação a Juião Bolseiro, Lourenço e Pai Calvo, trazemos um novo dado que não pode deixar de ser tido em consideração, em particular no caso de Lourenço ${ }^{50}$ ), numa possível reavaliação da sua naturalidade.

A falta de apoio documental para o estabelecimento da naturalidade, condição social e cronologia destes autores é, como vemos, um dado comum a quase todos eles. Com a excepção de Ambroa, Pedr'Amigo e provavelmente Abril Peres,

(48) Ver ficha respectiva, em apêndice.

(49) José Mattoso, "Cavaleiros andantes: a ficção e a realidade», in Idem, A Nobreza Medieval Portuguesa. A Família e o Poder, Lisboa, 1981 , p. 359 e "A nobreza medieval galaico-portuguesa. A identidade e a diferença, Ler História. 1, 1983, pp. 15-16.

(50) Ver ficha respectiva, em apêndice. 
tudo o que deles podemos conhecer se baseia nas indicações retiradas do seu nome, das suas composições e da sua colocação. Para alguns deles, muito provavelmente, serão sempre os únicos elementos com que contaremcs. Tal facto conduz-nos a um terceiro elemento, que novamente os parece associar entre si: a sua condição de segreis ou jograis (v. fichas biográficas em apêndice). De condição popular ou nobre, mas neste caso de uma nobreza secundária e sem grandes meios de fortuna, assumindo a canção trovadoresca como uma profissão da qual esperavam retirar os dons necessários à sua subsistência, estes autores raramente terão deixado marca da sua presença na documentação da altura.

Verificada a coerência do conjunto e as suas prováveis características - ou seja a origem galega dos seus elementos e a sua categoria comum de jograis e segreis -, temos agora de examinar a sua cronologia. Com efeito, baseando-nos em dados internos e externos até agora descobertos pelos especialistas e pelos que indico nas biografias, verificamos que o autor mais recente deste conjunto é Airas Pais, jogral ao serviço de D. Sancho IV de Castela nos finais do séc. XIII. Nos inícios do séc. XIV mantém-se ainda activo, mas no nordeste peninsular. Consequentemente, o cancioneiro poderia ter sido organizado já nos finais do séc. XIII ou, o mais tardar, nos inícios do século seguinte. A sua incorporação no acrescento à secção das cantigas de amigo de $\omega$ seria, portanto, posterior a estas datas, mas anterior à inclusão no cancioneiro dos grupos de autores anteriormente analisados.

A ser aceite a nossa argumentação, a definição deste cancioneiro vem redimensionar o estudo da cultura trovadoresca galego-portuguesa em várias vertentes. Gostaríamos, para concluir, de esboçar algumas delas. Em primeiro lugar, do ponto de vista da tradição manuscrita e ac acrescentar mais um cancioneiro aos anteriormente conhecidos, introduz um novo dado para se reavaliar a genealogia proposta por G. Tavani para a fase inicial dessa tradição, no que diz respeito aos cancioneiros propriamente ditos. Em segundo lugar, e tomando agora em linha de conta a sociologia dos autores aqui presentes, nota-se a feição mais jogralesca que tomou a cultura trovadoresca na Galiza, ao contrário do verificado em Portugal. Apesar de relativizada pelos trovadores galegos inseridos no resto do cancioneiro, essa feição não deixa, mesmo assim, de ser significativa da divergência das soluções encontradas em ambas as regiōes no momento de assimilarem uma manifestação cultural nascida além Pirenéus. O sinal maior dessa divergência é, sem dúvida, o peso esmagador das cantigas de amigo neste cancioneiro, mais uma vez em contradição com o que acontece em $\omega$. 


\title{
Revista de História das Ideias
}

Registe-se, ainda, o tecto cronológico proposto para todos eles. Com excepção de Airas Pais, nenhum daqueles cuja obra pode ser minimamente datada ultrapassará em muito o terceiro quartel do séc. XIII. Portanto, até que novos elementos biográficos venham, eventualmente, a pôr em causa as balizas cronológicas apontadas, poderão situar-se antes de c. 1275 os autores mais obscuros, e que até agora se consideravam impossíveis de datar.

\section{O cancioneiro de João Airas de Santiago}

\author{
(16) Pero Anes Marinho \\ (18) João Airas de Santiago - c. amor \\ (27) João Airas de Santiago - c. amigo \\ (27/2) Rui Martins
}

Atendendo ao número das suas composições, mais de 80 , à sua colocação e a uma organização por géneros pcéticos, é quase certo estarmos perante um dos cancioneiros individuais acrescentados - depois de finais do séc. XIII - a $\omega\left({ }^{51}\right)$. A ordenação é idêntica à do cancioneiro galego: primeiro, as cantigas de amor, depois, a pouca distância, as cantigas de amigo e, finalmente, as cantigas de escárnio na respectiva secção, mas integradas no núcleo original de $\omega$.

A sua feitura e posterior inserção neste cancioneiro devem ter sido sensivelmente contemporâneas do cancioneiro galego. Após esta inserção, deve ter sofrido alguns arranjos na zona de separação entre as cantigas de amor e as cantigas de amigo, com o deslocamento de autores da secção das cantigas de amor para essa zona e ccm o acrescento de novos autores portugueses. Talvez por isso, Pero Anes Marinho, que iniciaria as cantigas

(51) José Luis Rodríguez, na sua edição da obra de João Airas (v. ficha respectiva), e apoiado na repetição do seu nome no grupo das cantigas de escárnio e maldizer e também na repetição de duas das cantigas de amigo, é de opinião contrária. $\mathbf{O}$ exame atento de $\mathbf{B}$ refuta a primeira objecção, porquanto a duplicação da rubrica atributiva se deveu a Colocci, após engano do copista (ed. cit., pp. 647-649). Quanto à repeticão de duas cantigas de amigo, a admitir-se uma dupla atribuição, ela pode ter existido antes da compilação do cancioneiro individual e, por descuido ou indecisão do copista, ter deixado alguns traços no cancioneiro. 
de amigo deste autor - a sua cantiga de amor está dependente da primeira cantiga de amigo de João Airas -, nos apareça hoje um tanto deslocado, na parte final do grupo dos clérigos. A última composição do grupo das cantigas de amigo deste autor é uma tenção, incompleta, com um jogral de nome Rui Martins. E única referência conhecida a este jogral, daí a sua inclusão na sequência inicial, embora com a numeração deste grupo de composições de João Airas.

6. O grupo de clérigos
(5) Airas Nunes
(6) A. Gomes
(9) Martim Moya
(13) D. Gomes Garcia
(14) Rui Fernandes
(15) Pai de Cana
(17) Sancho Sanches

Deve ter sido o primeiro núcleo, com alguma importância, acrescentado a $\omega$. A colocação de A. Gomes, jogral de Sarria, depende de Martim Moya (v. fichas de ambos). Daí a manutenção da sua colocação neste grupo. Aquilo que liga todos estes autores é apenas a sua pertença a um mesmo estrato social. Ao contrário de João Airas ou do cancioneiro galego, não se vislumbra aqui qualquer tipo de organização para as composições. A sua reunião pode ter ocorrido por mera junção das folhas ou rolos nos quais estavam transcritas as cantigas, e pode ter sido efectuada antes ou mesmo na altura da sua incorporação no acrescento em análise.

Com excepção de Sancho Sanches, do qual nada se sabe de concreto, os autores mais tardios deste grupo, D. Gomes Garcia e Airas Nunes, situam-se no âmbito da corte de Sancho IV de Castela, na década de oitenta do séc. XIII. A composição de A. Gomes, pela referência a Martim Moya, poderá ser também desta altura ou talvez um pouco anterior. O agrupamento destes autores, se anterior ao seu acrescento ao arquétipo, poderá assim ter-se verificado nos últimos anos do séc. XIII ou no primeiro quartel do séc. XIV. 


\section{Revista de História das Ideias}

\section{Mendinho}

\section{(1) Mendinho}

Deixamos para o fim o autor cuja colocação é mais difícil de elucidar ( $v$. ficha respectiva), porquanto nos surge numa encruzilhada de tradições manuscritas diferentes, mantendo relações algo contraditórias com aquelas em que poderia ser eventualmente inserido. A solução, no entanto, deve estar numa de duas opções possíveis, embora não completamente satisfatórias:

\section{1-Presença em $\omega$.}

Possuindo somente uma cantiga de amigo, Mendinho aparece correctamente incluído na respectiva secção, no fim de um conjunto de trovadores com o mesmo tipo de composições e imediatamente antes dos primeiros autores acrescentados a essa seç̧ão, já no séc. XIV, com cantigas de amor. Neste contexto, e não possuindo cantigas de amor nem cantigas de escárnio, seria o último autor da secção das cantigas de amigo de $\omega$. Tratando-se, todavia, de um cancioneiro de cavaleiros, como se depreende da rubrica que anuncia esta mesma seç̧ão, a sua provável condição de jogral não se coaduna bem com esta solução.

2 - Autor do cancioneiro galego.

Pela sua naturalidade, pela sua condição de jogral e também pela composição dele conservada, pertenceria naturalmente ao cancioneiro galego. A sua colocação não o aproxima, porém, deste cancioneiro, a não ser admitindo a hipótese de um deslocamento da sua cantiga de amigo para uma zona diferente da inicial. $\mathrm{Da}$ análise do quadro geral não retiramos, todavia, quaisquer indicações nesse sentido. Esta hipótese, apesar de tudo, é a que nos parece mais credível. Daí a colocacão que lhe destinamos, no início deste acrescento, e a sua discussão neste local.

\section{Conclusão}

A análise do mais importante acrescento feito a $\omega$, vem trazer-nos alguns elementos para podermos ajuizar com maior rigor o que se passou no domínio da tradição manuscrita, na passagem do séc. XIII para o séc. XIV, numa altura em que a cultura trovadoresca, atravessado um já longo caminho, encontrara um apoio de relevo nas principais cortes régias do ocidente peninsular. 
Sobressai, desde logo, a efervescente actividade na compilação de cancioneiros colectivos. À primeira grande compilação, (1). juntara-se uma sua cópia parcial, A, e, pela mesma altura, reunia-se também a produção poética de um conjunto vasto de autores galegos. O cancioneiro de João Airas de Santiago, apesar de individual e a admitir-se a hipótese que propomos, merece também algum destaque pelo número de composições que alberga. Atendendo à nova cronologia gizada para a actividade deste autor, é muito provável que a sua compilação se tenha efectuado pela mesma altura.

Um segundo elemento a destacar é a homogeneidade verificada na organização destes cancioneiros. Em todos eles, com efeito, se respeita uma divisão tripartida, reveladora da consciência da distinção entre os principais géneros poéticos praticados. Mais, a hierarquização dos géneros é a mesma em todos eles. As compilações começam todas com as cantigas de amor, passam, de seguida, às cantigas de amigo, e concluem-se com a seriação das cantigas de escárnio e de maldizer. Um indicadcr, a juntar a outros, sobre o ou os locais de onde poderá ter partido este interesse pela reunião dos autores em cancioneiros.

O grupo dos clérigos levanta outros problemas. Próximo, pelo espírito de compilação, dos anteriores, afasta-se deles pela desorganização que presidiu à sua feitura. Perante este facto, será talvez mais seguro considerar esta compilação como resultado de um interesse individual, certamente de um clérigo sem ligação ao centro ou centros onde, pela mesma altura, se procedia também a compilações, mas com outros critérios. A não ser, como sugerimos, que a junção deste grupo se tenha dado apenas na altura da sua inclusão no acrescento analisado. Em qualquer dos casos, este grupo traz ainda bem visíveis os estigmas da tradição manuscrita anterior a finais do séc. XIII, momento em que dominavam os cancioneiros individuais ou folhas e rolos com composições de um ou mais autores, sem quaisquer preocupações de sistematização e de ordenação $\left({ }^{52}\right)$.

Se esta compilação obedecesse às regras dos cancioneiros referidos anteriormente, teríamos fortes razões para acrescentar uma nova tripartição para além da referente à organização interna dos cancioneiros, isto é, estaríamos perante a feitura, em simultâneo ou quase, de três cancioneiros, um de cavaleiros, o segundo jogralesco e o último clerical. Constituíriam então, no seu conjunto, uma espécie de «cancioneiro geral» da cultura

(52) Sobre esta fase da tradição manuscrita v. Tavani, Grundriss, pp. 33 e $37-9$. 
trovadoresca galego-portuguesa tal como ela se tinha desenvolvido até finais do séc. XIII.

Esta nova tripartição, a existir, complicaria a situação de $\omega$ como primeiro momento, no stemma codicum proposto por Tavani, das grandes compilações trovadorescas $\left(^{53}\right)$. Assinale-se, todavia, que se de um cancioneiro clerical obedecendo à organização dos anteriores não há quaisquer vestígios, há-os de um cancioneiro de tipo jogralesco. Do ponto de vista da tradição manuscrita, a conclusão lógica a tirar, parece-nos, é a de que a partir de agora não se poderá confundir $\omega$ com um hipotético «cancioneiro geral» da lírica galego-portuguesa, a não ser com a ressalva de que representará de facto esse «cancioneiro geral» mas somente da sua vertente mais aristocrática.

A detecção da corte ou cortes de onde partiu a confecção destes cancioneiros e o modo como posteriormente foram acrescentados ao arquétipo de $\mathrm{A}$, não nos ocuparão de momento. Exigiriam uma análise global de todos os acrescentos a este mesmo arquétipo, assunto fora do nosso propósito desde o início, e, além disso, obrigar-nos-iam a combiná-la com a actividade cultural e política da sociedade cortesã do ocidente peninsular de fins do séc. XIII e primeira metade do séc. XIV, alongando em demasia este trabalho. Contamos voltar ao tema em tempo oportuno, esperando trazer algumas certezas a este ainda obscuro problema ${ }^{(54)}$.

A actividade compilatória registada nos fins do séc. XIII ou, o mais tardar, nos inícios do séc. XIV, não se manteve com a mesma constância ao longo da primeira metade deste século. Da Galiza, de Leão ou de Castela, não só não se conhecem contributos importantes, como também a análise de $\mathrm{B}$ e $\mathrm{V}$ não nos conduz nesse sentido. Em relação a Portugal, uma conclusão semelhante pode retirar-se da colocação dos autores portugueses no acrescento analisado, onde, com poucas excepções, nos aparecem com um reduzido número de composições. Estas, circulariam em folhas volantes ou rolos, acrescentados a $\omega$ talvez à medida que o compilador os ia recolhendo. B conservou provavelmente um resíduo dessa situação na obra de Pero Mendes da Fonseca (.$^{\circ}$ 46). Com efeito, as suas 5 cantigas de amor são aí antecedidas pela indicação "Outro $\mathrm{R} .^{\circ}$ se comeca assy» e, mais abaixo, «R. ${ }^{\circ}$ par deus senhor quero m'eu hir», transcrevendo o primeiro verso da primeira cantiga deste autor $\left(^{55}\right)$. E, no entanto, admissível a presença, em casos

(53) Idem, ibidem, pp. 34-6.

(54) Veja-se, no entanto, Tavani, Grundriss, pp. 345 e 42-3.

(55) Antes de B 1122 (p. 516). 
A P E N D I C E S

TRE $\omega$ e $\alpha$

A. AM. ES.

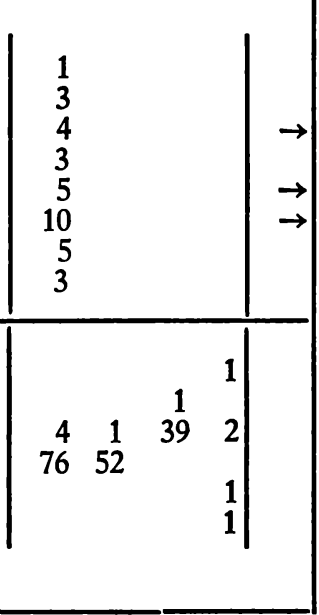

r comparação com outro ou outros e nesse cancioneiro, surge em local

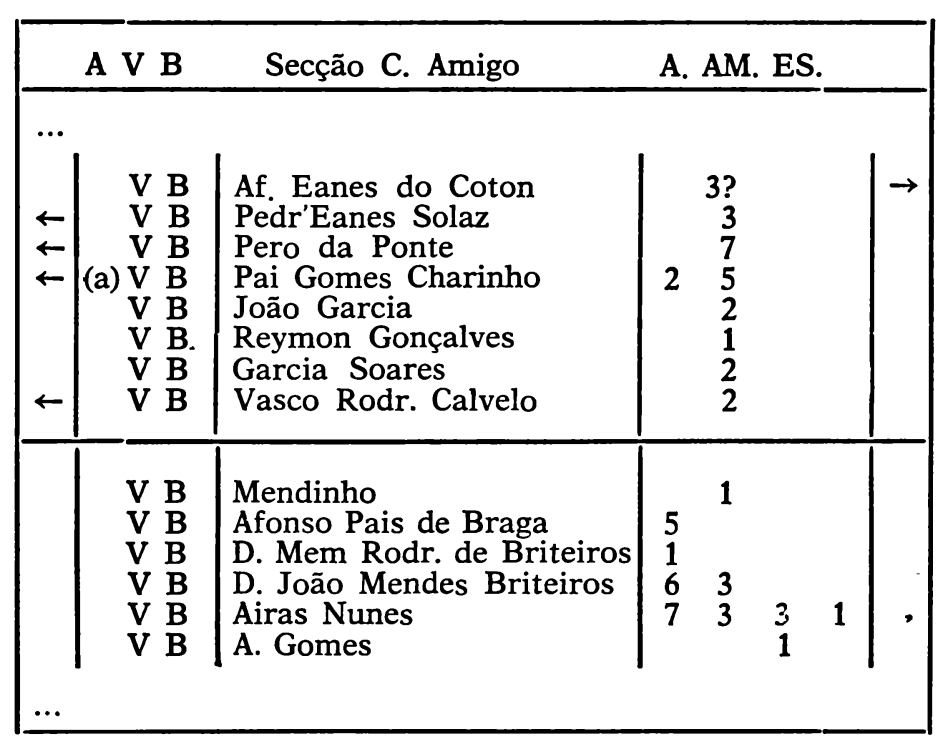

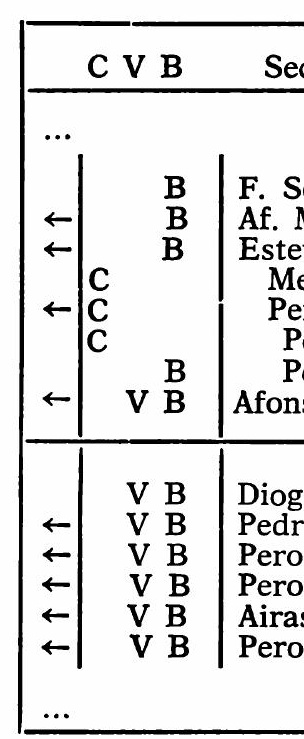

GEN. POÉTICOS:

quarta coluna-composições que não pertencem a ne três grandes géneros poéticos

SETAS: - idêntica colocação do autor noutra seç̧ão do m cioneiro $(\omega$ ou $\alpha$ ). 



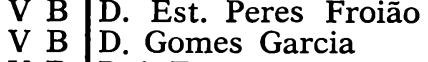

Rui Fernandes

Pai de Cana

Pero Anes Marinho

V B Sancho Sanches

V B João Airas de Santiago

$V$ B Af. Eanes// [AN.]

V B Airas Engeitado

V B Rodr. Eanes d'Alvares

(A) V B Fernão Padrom

(a) V B Pero da Ponte

(a) v b Vasco Rodr. de Calvelo

$\mathrm{V} \mathbf{b}$

V

$\mathrm{V}$ b

V $\mathrm{B}$

V B

V $\mathrm{B}$

Rui Martins de Oliveira

D. Pero Gomes Barroso

João Airas (+Rui Martins)

Martim Peres Alvim

B. Bonaval (+Abril Peres)

João Sernando

V B [Diogo Gonç. de Montemor]

V B Juião Bolseiro

$V$ [AN.]

V B Pero de Armea

V B Est. Fern. de Elvas

$V$ B Pedro Amigo de Sev.

V B Airas Pais

V B Lourenço

V B João Baveca

V B Galisteu Fernandes

V B Lopo

V B Lourenço

V B João

V B Pero de Berdia

V B Pero Mendes Fonseca

V B Nuno Porco

V B Pero de Ver

V B Bernal de Bonaval

V B João Sernando

V B João Zorro

V B Rui Martins do Casal

\begin{tabular}{ll|l} 
V & B & [AN.] \\
V & B & Juião Bolseiro
\end{tabular}

V B Martim Campina

V B Pero Meogo

V B Martim de Caldas

V B Nuno Trez

V B Pero de Armea

V B Pedro Amigo de Sev.

(A) v b Pedro Anes Solaz

V B João Baveca

V B Pero de Ambroa

V B Pai Calvo 

excepcionais, de cancioneiros individuais onde, como em João Airas, se observou o princípio da divisão por géneros. A colocação das composições de Estevão da Guarda e a observação rigorosa, nela verificada, dessa divisão (v. ficha respectiva), sugerem esta possibilidade para este autor $\left({ }^{56}\right)$.

A viragem do século fechou, assim, o período das grandes compilações da comunidade trovadoresca do ocidente peninsular. A tradição manuscrita posterior, privilegiando os autores portugueses, revela um certo retraimento geográfico desta manifestação cultural, confinando-a praticamente ao território português. Uma imagem certamente sem correspondência com a realidade, mas que não deixa de reflectir, de qualquer modo, a importância da presença portuguesa no processo de transmissão manuscrita por volta de meados do séc. XIV. Aquele através do qual podemos chegar hoje ao conhecimento desta manifestação cultural.

(56) Outro exemplo, este conhecido, é o do cancioneiro de D. Dinis, cujas componentes principais estão integradas no acrescento à secção das cantigas de amor de $\omega$. Cf. Tavani, Grundriss, pp. 39-41. 


\section{OS AUTORES DO ACRESCENTO A SECÇÃO DAS CANTIGAS DE AMIGO DE $\omega$; DADOS BIOGRAFICOS E COLOCAÇÃO}

Reunem-se neste apêndice, e para cada um dos compositores presentes no acrescento analisado, os vários elementos cujo exame tornou possível a definição de uma estratigrafia para esta zona dos cuncioneiros $\mathrm{B}$ e V ou, se se quiser, de $\alpha$. Cada ficha individual comporta não só uma análise crítica da colocação do autor respectivo, mas também os elementos de ordem biográfica que nos permitem situá-lo no contexto da manifestação cultural em que se inseriu.

Para a discussão da colocação de cada um deles tivemos em conta o tipo de composições que nos deixou, a eventual presença noutras zonas do cancioneiro e, quando necessário, a sua condição social. A terminologia utilizada nesta discussão - secções, acrescentos d secções, $\omega$, etc. - resulta já da tentativa de clarificação da evolução do cancioneiro entre $\omega$ e $\alpha$, levada a cabo na segunda parte do trabalho.

$\mathrm{Na}$ parte biográfica aproveitamos, sempre que possível, os elementos já conhecidos. A pesquisa entretanto efectuada na documentação medieval permitiu-nos, no entanto, trazer dados novos que contribuirão, por certo, para um melhor conhecimento de alguns autores e, em última análise, para uma compreensão mais cabal da evolução da cultura trovadoresca no ocidente peninsular. Porque o trabalho não o justificava, não tivemos preocupações de exaustividade neste campo, cingindo-nos aos elementos considerados essenciais para definir a cronologia e geografia do autor em causa. Registe-se, finalmente, que a indecisão presente nalgumas biografias poderá ser atenuada após a análise da estratigrafia deste acrescento. Remetemos, portanto, para essas páginas, para esclarecimentos que possam vir a ser feitos em relação a alguns autores.

\section{ABRIL PERES

$$
\text { (n. }{ }^{\circ} \text { 30/2) }
$$

A sua única composição, uma tenção com Bernal de Bonaval, encontra-se inserida na obra deste autor (v. ficha respectiva).

Não citando quaisquer personagens, essa composição liga-o, no entanto, ao segrel galego Bernal de Bonaval, cuja actividade poética se situa na primeira metade do séc. XIII (1). Foi à volta deste elemento e do conhecimento de indivíduos com o mesmo nome, que girou o problema da identificação deste autor. As principais posições sobre o mesmo foram definidas logo nos inícios deste século, quer a favor de um Abril Peres, burguês de Santiago de Compostela ( ${ }^{2}$ ), quer a favor do magnate português D. Abril Peres de Lumiares ( ${ }^{3}$ ). Os investigadores subsequentes, mais cautelosos é certo, acabaram por optar por uma ou por outra posição. Trata-se de um caso exemplar das dificuldades de atribuição de composições cuja indicação de autoria é de certo modo ambígua e não encontra fora dos cancioneiros elementos que a esclareçam.

\footnotetext{
(1) Maria Luisa Indini, Bernal de Bonaval, Poesie, Bari, 1978, pp. 9-27.

(2) António Lopez Ferreiro, Historia de la Santa A.M. Iglesia de Santiago de Compostela, t. V, Santiago de Compostela, 1902, p. 375.

(3) Michaëlis, CA, II, pp. 298-300, 655.
} 


\section{«Livro das Cantigas» do Conde D. Pedro}

Num documento de 18 de Junho de 1221, do mosteiro de S. Vicente de Fora, de Lisboa, aparece como testemunha um D. Abril, jogral (4). Sendo a única indicação que possuimos da existência de um indivíduo com este nome associado ao meio trovadoresco peninsular podemos, muito provavelmente, estar perante o Abril Peres dos cancioneiros medievais. Yor outras palavras, Abril Peres seria um jogral sediado em Lisboa nos inícios do séc. XIII. Essta situação é, todavia, paradoxái. Lom etelto, encontramo-nos aunda numa tase de arranque desta manitestação cultural e todos os restantes elementos conneciuos apontam inequivocamente as regiões da Gallza e Norte de Portugal como polos do seu desenvolvımento inicıal. A explicação deste desıocamento geogrático poderá estar, pelo menos em parte, no documento mencionado. Aí, $\nu$. Abril surge-nos associado aos Sousas, uma das tamulas nuores portuguesas mais importantes do séc. XIII, cujos bens patrimoniais se situavam, a Norte do Louro, nas terras de Aguıar de Sousa, Penatiel, Santa Cruz e Felgueiras $\left(^{5}\right)$. A sua categoria ae jogral sugere que tosse um dependente aa corte senhorial desta importante lunhagem e que os teria acompanhado numa desıcação para fora da área em que normalmente viviam. Neste contexto fica de pé a hipótese de um jogral de origem galega ao serviço dos Sousas, mas excluída, a não ser que se recuse a identificação com o indivíduo registado em Lisboa, a atribuição da tenção com Bernal de Bonaval a Abril Peres de Lumiares.

\section{AFONS'EANES (DO COTON) (n. ${ }^{\circ}$ 19)}

Situado neste acrescento com duas cantigas de amor e uma tenção com Pero da Ponte.

Se tivermos em conta $\omega$, as suas cantigas de amigo e a maior parte das cantigas de escárnio surgem colocadas nas respectivas secções, entre outros autores seus contemporâneos e já na parte final desse cancioneiro $\left.{ }^{(}\right)$. 0 mesmo não se passa com as suas cantigas de amor. Em vez de surgirem na parte final da respectiva secção, aparecem integradas na seç̧ão das cantigas de amigo, na parte acrescentada a $\omega$ e na sequência dos vários clérigos aí inseridos. Uma anomalia deste tipo não é, no entanto, específica das composições deste autor. As cantigas de amor de Pedr'Eanes Solaz, Fernão Padrom, Pero da Ponte, Vasco Rodrigues de Calvelo, Martim Moya e Rui Fernandes de Santiago, todos eles presentes em A, foram deslocados parcial ou totalmente, para o mesmo acrescento. Uma possível explicação para este deslocamento poderá estar na reformulação da parte final da secção das cantigas de amor de $\omega$, ou de uma sua cópia - o que explicaria as divergências entre $\mathrm{A}, \mathrm{B}$ e $\mathrm{V}$ nesta zona - , aquando da incorporação, na primeira metade do séc. XIV, de novos autores nessa parte do cancioneiro. A associação de ambos os deslocamentos, o de Coton e $\boldsymbol{o}$ dos restantes autores mencionados, leva-nos a formular uma última

(4) TT-S. Vicente, m. II, doc. 15. Trata-se de uma carta de confirmação, por D. Guiomar Mendes de Sousa, de uma venda feita por seu irmão D. Gonçalo Mendes. Devemos esta preciosa indicação à amabilidade da nossa colega Dr.a Leontina Ventura.

(5) José Mattoso, Identificação de um Pais, I, Lisboa, 1985, pp. 158-161.

(6) A sua colocação em $\omega$ poderá ser vista no quadro da zona de intersecção entre $\omega$ e $\alpha$, em apêndice. Para as explicações que se seguem deve-se, igualmente, ter presente 0 mesmo quadro. 
hipótese. Na secção das cantigas de amigo de $\omega$, a Coton seguem-se Solaz e Ponte. Se voltarmos agora à secção das cantigas de amor do mesmo cancioneiro, representado por A, verificamos que a colocação é idêntica para os dois últimos autores. Entre eles, situa-se apenas Fernão Padrom de quem se conservaram somente cantigas de amor. As composições que antecedem Solaz, porque conservadas apenas por Aonde não existem rubricas atributivas -, não tem autoria segura. $\mathrm{O}$ mesmo cancioneiro indica, pelo espaço reservado para as miniaturas, tratar-Se de três autores diferentes. Ora, se nesta secção existiu, originalmente, uma sequência semelhante à da secção das cantigas de amigo, um desses três autores anónimos será Afons'Eanes de Coton.

A biografia de Coton tem estado dependente das suas composições. Aparece relacionado com Martim Soares e com Pero da Ponte, autores cuja obra se situa em boa parte na primeira metade do séc. XIII ( ${ }^{7}$ ). Numa célebre composição de Afonso X, em que Pero da Ponte é acusado de roubar os versos de Coton, este autor é dado já como falecido. Segundo Menéndez Pidal ( $\left.{ }^{8}\right)$ era natural da Corunha. A sua condição de segrel - diz-se escudeiro, numa das suas cantigas - levou-o, pelo menos, a Leão e a Castela.

\section{A. GOMES, jogral de Sarria \\ (n.*6)}

A sua presença e colocação no cancioneiro parece dever-se ao autor que o segue, Martim Moya. De facto, a única composição dele conservada é uma cantiga de maldizer dirigida àquele trovador, onde satiriza a sua longevidade. É provável que a sua inclusão no grupo dos clérigos presentes nesta zona do cancioneiro se deva ao facto desta composição ter andado inserida na obra de Martim Moya $\left.{ }^{(}\right)$.

Segundo a rubrica que antecede a sua composição em $B$ e V, era jcigral de Sarria. A falta de outros elementos, a sua cronologia está dependente da de Martim Moya. A referência à sua velhice deve colocá-lo na geração posterior à deste trovador.

\section{AFONSO PAIS DE BRAGA (n..$^{\circ}$ )}

Surge com cinco cantigas de amor, as únicas que dele possuimos, na parte inicial do acrescento à secção das cantigas de amigo de $\omega$. Tal facto revela que a sua inclusão se verificou já nos fins do séc. XIII ou na primeira metade do séc. XIV. Pela colocação no cancioneiro, aparece associado a dois outros trovadores portugueses, D. Mem Rodrigues de Briteiros e D. João Mendes de Briteiros, que comungam com ele de idêntica situação.

Da linhagem dos Braga, os livros de linhagens medievais portugueses conservaram apenas a memória de D. Sancha Martins de Braga

(7) Michaëlis, CA, II, respectivamente pp. 321-36 e 450-64.

(8) R. Menendez Pidal, Poesia juglaresca y juglares, Madrid, 19757, p. 109 (a partir de agora apenas Pidal, Poesia). Cf. Saverio Panunzio, Afons'Eanes do Coton», in Grande Dicionário da Literatura Portuguesa e de Teoria Literária, dir. por João José Cochofel, I, Lisboa, 1977, pp. 69-70. G. Tavani, Grundriss, fasc. 8, 1983, p. 9.

(9) Esta inserção é uma das hipoteses avançadas já por Luciana Stegagno Piochio, Martim Moya. Le Poesie, Roma, 1968, p. 56. 
pelo facto de ter casado com Pero Salvadores de Urgeses (10). Em 1258 os filhos de ambos possuíam um casal em S. Eulália de Fermentões, junto ao rio Selho e perto de Guimarães. Nessa mesma povoação, e também com um casal cada, concorrem uma D. Elvira de Braga e um Afonso Pais, que pensamos ser o nosso trovador. E certamente o mesmo Afonso Pais que, com Paio Peres e Afonso Gonçalves, tinha feito uma grande vinha num reguengo do rei, na paróquia vizinha de S.ta Maria ue Silvares (11). Corroborando a ligação aos Briteiros, presente nos Cancioneiros, assinale-se que esta linhagem era natural desta mesma região. A ser correcta esta identificação, Afonso Pais de Braga sera contemporâneo de Mem Rodrigues de Briteiros, também referido nas Inquirições de 1258 e ainda vivo nos inícios do séc. XIV.

\section{AIRAS ENGEITADO (n. 20$)$}

Conservaram-se deste autor três cantigas de amor, colocadas pouco depois do grupo dos clérigos. Dada a sua ausência de A, pode pensar-se numa inclusão tardia, nos fins do séc. XIII ou já na primeira metade do séc. XIV. Aparece associado ao trovador português Rodrigu'Eanes d'Alvares e, se a hipótese levantada para Afons'Eanes de Coton é correcta, entre vários trovadores cujas cantigas de amor, presentes em parte em A, foram posteriormente deslocadas para esta zona da secção das cantigas de amigo.

Não foram ainda encontrados elementos documentais que permitam situá-lo cronológica e geograficamente. A sua ligação, nos cancioneiros, a Rodrigu'Eanes d'Alvares não indica necessariamente estarmos perante um autor português, embora este elemento, associado ao facto de dele se conhecerem apenas cantigas de amor, possa induzir-nos nesse sentido (12).

\section{AIRAS NUNES clérigo (n. ${ }^{\circ}$ )}

Com excepção de uma cantiga de escárnio, as suas composições, incluindo cantigas de amor, cantigas de amigo, cantigas de escárniu e de maldizer, encontram-se reunidas no amplo conjunto de autores acrescentados à secção das cantigas de amigo de $\omega$ e no início do gi:upo dos clérigos aí presentes (13). A sua inclusão numa data posterior à da feitura de $\omega$ ressalta do desrespeito, verificado na sua obra, por uma ordenarão de autores após prévia divisão do cancioneiro por géneros poéticos. No seu caso, surgindo associado a vários outros clérigos, parece ter sido privilegiado o estatuto social como elemento organizador e não o seu contributo enquanto trovador. Estas considerações podem estender-se, aliás, aos restantes clérigos, cuja obra revela îtêntica rebeldia às regras da compilação inicial.

(10) Livro de Linhagens do Conde D. Pedro, ed. crítica de José Mattoso, Lisboa, 1980, 49A4 (a partir de agora apenas LC).

(11) Portugaliae Monumenta Historica. Inquisitiones, 9 fasc. publ., Lisboa, 1888-1977 , p. 719 a 720 b (a partir de agora apenas Inq.).

(12) Tavani, apoiando-se em elementos temáticos e estilísticos, coloca-o em meadoe ou no terceiro quartel do séc. XIII. Cf. Grundriss, fasc. 6, p. 159.

(13) Sobre a dupla tradição manuscrita dessas composições, ver G. Tavani, Le poesie di Ayras Nunez, Milæo, 1964, pp. 14-17. 


\section{Revista de História das Ideias}

Apoiado em duas referências a ele feitas num registo de contas da Chancelaria de D. Sancho IV de Castela para os anos de 1283-1286 e também nos temas e personagens citados nas suas cantigas de escárnio e de maldizer, Tavani pode definir, com exactidão, o âmbito cronológico da sua actividade poética bem como o círculo cortesão que terá frequentado. Trata-se de um clérigo, provavelmente galego, ao serviço de Sancho IV nos anos de 1284 a 1289 (14).

\section{AIRAS PAIS, jogral \\ (n.os 38 e 73)}

Integrado apenas nesta zona da secção das cantigas de amigo, surge aí em dois locais diferentes. No primeiro (n.*38) com duas cantigas de amor e no segundo (n. ${ }^{\circ}$ ) com duas cantigas de amigo. Esta situação, pouco natural caso tentássemos inseri-lo no conjunto de autores subordinados à ordenação de $\omega$, associa-o no entanto a um grupo de dez autores cuja inserção é idêntica à sua: Pero de Ver, Bernal de Bonaval, João Servando, Juião Bolseiro, Pero d'Armea, Pedr'Amigo de Sevilha, Lourenço, João Baveca, Galisteu Fernandes e Lopo. Em todos eles se verifica uma distribuição por dois locais diferentes, com a excepção irrelevante de Lourenço, que ocupa três lugares, correspondente ao mesmo tempo a uma diferenciação de géneros poéticos. Entre os n. ${ }^{\circ} 29$ e 43, aparecem-nos todos eles pela primeira vez com as suas cantigas de amor, repetindo-se os seus nomes entre os n..$^{\circ} 48$ e 73, agora com as suas cantigas de amigo. Ordenação singular, em que os autores aparecem dimensionados apenas para esta parte do cancioneiro, quebrada somente nos casos em que as respectivas cantigas de escárnio foram deslocadas para a secção correspondente.

A referência, numa das suas cantigas de amigo, à ermida de S. Maria de Reça, dá-lhe como naturalidade provável a região de Orense, na Galiza. Em 1293 era um dos jograis ao serviço de D. Sancho IV de Castela, mantendo-se ainda em actividade, no nordeste peninsular, nos inícios do séc. XIV (15).

\section{Anónimo$$
\text { (n. } 19)
$$

Fragmento de uma composição inserida no interior da obra de Afons'Eanes do Coton. D'Heur pôs a hipótese de se tratar de uma interpolação tardia (16). Em V são transcritos os quatro primeiros versos, aos quais se segue um pequeno espaço em branco no fim da página. $\mathrm{B}$, mais cauteloso nestes casos, transcreve o primeiro verso, "A quantos sabem trobar», deixando cerca de meia página em branco.

(14) G. Tavani, Le poesie...., pp. 22-27, e Grundriss, fasc. 8, pp. 11-12.

(15) Cf. José Joaquim Nunes, Cantigas de Amigo dos trovadores galego portugueses, I, Lisboa, 19732, pp. 192-3 (a partir de agora apenas Nunes, Amigo) e Pidal, Poesia, p. 133.

(16) Jean Marie D'Heur, Nomenclature des troubadours Galiciens Portugais (XIIe-XIVe siecles)», Arquivos do Centro Cultural Portugues, vol. VII, Paris, 1973, p. 37 (n.० 972 ). 


\section{Anónimo \\ (n.o 34)}

Interpolação tardia (17). Transcrição integral em $\mathrm{V}$, entre as cantigas de amor de Juião Bolseiro e de Pero d'Armea. O copista de B, notando certamente, pelo tipo de letra diferente, tratar-se de um acrescento ao códice que copiava, avançou para o autor seguinte, Pero d'Armea, esquecendo-se todavia de assinalar a mudança de autor.

\section{Anónimo (n. 53)}

Quatro fragmentos de composições, inseridas na continuação da obra de Rui Martins do Casal e antes das cantigas de amigo de Juião Bolseiro. Trata-se novamente de uma interpolação tardia, exterior ao âmbito da canção trovadoresca, conservada por ambos os cancioneiros do séc. XVI (18).

\section{BERNAL DE BONAVAL (n.os 30 e 49 )}

Colocação idêntica à de um grupo de dez autores presentes nesta zona do cancioneiro (V. Airas Pais). Assinale-se a rubrica que, em ambos os cancioneiros do séc. XVI, antecede as suas cantigas de amor (n. 30 ): "En esta folha adeante se comenzan as cantigas d'amor. Primeyro trobador Bernal de Bonavalle». Colocada neste lugar dos cancioneiros, isto é, bem no interior da secção das cantigas de amigo, esta rubrica não deixa de causar alguma perplexidade. A partida, poder-se-ia pensar que este autor, na fase inicial da compilação, isto é, em $\omega$, apareceria logo no início da seccão das cantigas de amor, encabeçando esse mesmo cancioneiro. Com efeito, na passagem da secção das cantigas de amor para a das cantigas de amigo e desta para a das cantigas de escárnio e de maldizer, os cancioneiros do séc. XVI conservaram rubricas idênticas. Tal hipótese, no entanto, só teria cabimento se a posição do autor na secção das cantigas de amigo, para além de anómala em relação a $\omega$ - como parece ser o caso-, não o ligasse a um conjunto de outros autores que com ele partilham de idêntica inserção nessa zona. De facto, as suas cantigas de amigo não surgem no início da respertiva secção de $\omega$, como deveria acontecer no sentido de tornar credível a hipótese formulada, mas após as suas cantigas de amor, incluídas no acrescento a essa secção e integradas ambas num conjunto mais amplo que obedece à mesma hierarquização. Perante isto, apenas uma segunda hipótese se nos coloca: tratar-se de uma rubrica indicadora do início da secção das cantigas de amor de um cancioneiro diferente de $\omega$.

Segrel galego da primeira metade do séc. XIII. A elucidação da sua geografia e cronologia tem-se apoiado fundamentalmente nas suas composições, nomeadamente na tenção com Abril Peres, e também nas referências que lhe são feitas em composições de outros auto-

(17) G. Tavani, Repertorio Metrico della Lirica Galego-Portoghese, Roma, 1967, pp. 452-3. D'Heur, Nomenclature.... p. 38 (n.० 1079). 1178-81).

(18) G. Tavani, Repertorio...., p. 503. D'Heur, eNomenclature...., p. 39 (n.os 


\section{Revista de História das Ideias}

res (19). Caso se confirme a identificação de um D. Abril jogral com Abril Peres (v. Abril Peres), a cronologia proposta adquire sem dúvida um. ponto de apoio mais firme.

\section{DIEGO GONÇALVES DE MONTEMOR-O-NOVO \\ (n. $\left.{ }^{\circ} 32\right)$}

Composição exterior à tradição trovadoresca $\left({ }^{20}\right)$. Incluída em V e $B$, mas neste sem indicação de número. É precedida pela rubrica: "Pregunta que foi feita a Fernão d'Ataide (?)».

Um Diego Gonçalves, sem indicação de naturalidade, e um D. Fernão de Ataíde aparecem fugazmente no Cancioneiro Geral de Garcia de Resende (21).

\section{ESTEVAO FERNANDES D'ELVAS (n. 36$)$}

Integrado, com três cantigas de amigo, num grupo de autores (n.os 29-31, 33, 35, 37-43) que comparecem nessa zona apenas com cantigas de amor. Este elemento permite-nos pensar estarmos perante um caso de inclusão posterior a esse núcleo de autores. Por outro lado, os dois compositores que ele separa, Pero d'Armea e Pedr'Amigo de Sevilha, aparecem juntos na sequência seguinte de cantigas de amigo pertencentes a esse mesmo núcleo de autores (n.os 59 e 60). Registe-se, finalmente, o seu igual aparecimento no conjunto dos autores acrescentados à secção de cantigas de amor de $\omega$, próximo do conde $\mathrm{D}$. Pedro e de Estevão da Guarda.

Nada se sabe de concreto deste trovador português, natural de Elvas. Carmen M. Radulet (22), apoiando-se no facto de Estevão da Guarda ter utilizado o refrão de uma das suas composições, dá-o como contemporâneo deste autor. A sua colocação, quer na secção das cantigas de amor quer na secção das cantigas de amigo, confirma esta cronologia.

\section{ESTEVAO DA GUARDA}

(n. $\left.{ }^{\circ} 77\right)$

Com vinte e oito cantigas de escárnio e de maldizer, é um dos últimos trovadores a figurar na zona do cancioneiro em análise. Aí, ombreia com três autores: Fernand'Esquio, João Fernandes d'Ardeleiro e D. Mem Rodrigues de Briteiros, cuja obra não obedece a qualqueir organização prévia visível. A situação em que aparece nesta secção é idêntica à que se verifica na secção das cantigas de amor, onde é, mais uma vez, um dos últimos trovadores. Anote-se a preocupação, não totalmente conseguida, em distribuir a sua obra pelas três grandes divisões do cancioneiro: colocação correcta na secção das cantigas de amor, onde surge, na sua parte final, com seis cantigas de amor; insercão na secção das cantigas de amigo com uma composição desse

(19) Maria Luisa Indini, ob, cit., Bari, 1978, pp. 9-27.

(20) B. Tavani, Repertorio...., p. 403; D'Heur, Nomenclature....), p. 38 (n.॰ 1077).

(21) Cancioneiro Geral de Garcia de Resende, ed. de Alvaro J. da Costa Pimpăo - Aida Fernanda Dias, Coimbra, 1973, II, pp. 275 e 83.

(22) Carmen M. Radulet, Estevam Fernandez d'Elvas, Il Canzoniere, Bari, 1979. pp. 27-35. 
género, mas entre os trovadores da segunda metade do séc. XIII; finalmente, reaparecimento não no fim da secção das cantigas de escárnio e de maldizer, mas imediatamente antes dessa secção, ou seja, no fim do longo e heterogéneo acrescento à secção das cantigas de amigo de $\omega$.

Trovador português cuja actividade poética se pode situar, com segurança, na primeira metade do séc. XIV. Seria fastidioso e despropositado, de momento, enumerar todos os documentos que nos esclarecem sobre a sua biografia. É, sem qualquer dúvida, o trovador cujo nome aparece mais vezes na documentação régia portuguesa do período citado. Limitamo-nos a uma rápida súmula reveladora da sua longevidade e das principais fases da sua vida. E mencionado a primeira vez como escrivão régio, em 1299 (23). A sua fidelidade a D. Dinis, posta à prova nos conflitos que atravessaram os últimos anos de vida do rei, assegura-lhe não só uma presença constante na chancelaria, mas também a confiança do monarca, premiada com algumas doações e, facto não menos significativo, com a sua nomeação como seu testamenteiro. A partir de 1325 , com D. Afonso IV, a sua presença na corte é mais esporádica mas não menos significativa, aparecendo como conselheiro do rei e seu procurador em assuntos de política ibérica ${ }^{24}$ ). As suas cantigas de escárnio e de maldizer remetem a sua actividade poética para este período de maior afastamento da corte, ao longo do qual poderia dedicar também outra atenção aos seus vastos bens, situados ern Lisboa, Santarém, Torres Vedras, etc. Ainda vivo em 1362 (25), morre no entanto antes de Abril de 1364, altura em que Lourenço Martins do Avelal, casado com uma sua neta, reivindica alguns dos seus bens $\left({ }^{26}\right)$, sendo sepultado no mosteiro de S. Vicente de Fora, em Lisboa.

\section{ESTEVAO PERES FROIAO}

(n. ${ }^{\circ}$ 12)

A sua única composição, uma cantiga de amor, aparece inserida no conjunto de clérigos presentes no início deste acrescento à secção das cantigas de amigo. Para além de se tratar de uma inclusão posterior à da feitura de $\omega$, deve também ter-se verificado após o acrescento constituído por esse grupo de clérigos no qual surge inserido.

A associação entre Estevão Faião e Estevão Peres Froião, sugerida logo nos inícios deste século por Carolina Michaëlis (27), deve ser posta de parte. A colocação de ambos nos cancioneiros não facilita, desde logo, essa identificação. Estevão Faião é um autor, o mais tardar, de meados ou da segunda metade do séc. XIII, porquanto se encontra em $\omega$ (nas secções das cantigas de amor e de escárnio e maldizer), perfeitamente identificado, em termos de colocação e de géneros poéticos praticados, com a organização desse mesmo cancioneiro. Por outro lado há indícios da existência, em Portugal e na Galiza, de famílias com esse nome.

(23) TT - Chancelaria de D. Dinis, L. III, fl. 7v (a partir de agora, Ch. Dinis).

(24) Sobre a sua actividade na corte v. Armando Luis de Carvalho Homem, O Desembargo Régio (1320-1433), II, Porto, 1985, (Tese de doutoramento, policopiada), pp. 56-58 e quadros anexos - VII, 8.

(25) Chancelarias Portuguesas. D. Pedro I, ed. dir. por A.H. de Oliveira Marques, Lisboa, 1984, doc. 675.

(26) Ibidem, doc. 925.

(27) Michaëlis, $C A, \Pi$, pp. 415-6. 
Quanto a Estevão Peres Froião, a sua actividade, conhecida já por Carolina Michaëlis $\left({ }^{28}\right)$, desenvolveu-se nos fins do séc. XIII e início do séc. XIV, nas cortes de D. Sancho IV e D. Fernando IV de Castela. Com esta cronologia seria muito difícil vê-lo incluído em $\omega$. Da linhagem dos Pereira, não se sabe quando nem em que circunstâncias terá abandonado Portugal. Provavelmente cedo, visto seu pai - Pero Peres Homem - ser um dos cavaleiros portugueses herdados no repartimento de Sevilha ${ }^{29}$ ). O cognome vem-lhe certamente dos bens que o pai possuía no julgado de Froião, junto do rio Minho ${ }^{\left({ }^{30}\right)}$.

\section{FERNAND'ESQUIO \\ (n. 76$)$}

Um dos quatro autores a comparecer na parte final desta secção, onde não é visível qualquer ordenação prévia das composições. Esta heterogeneidade de géneros poéticos, na qual Fernand'Esquio participa com duas cantigas de amor e quatro de amigo, aliada à colocação propriamente dita, inclui-o no número de autores acrescentados tardiamente, já perto de meados do séc. XIV, nesta secção do cancioneiro. Completando a sua obra poética, duas ou três (31) cantigas de escárnio foram integradas na parte acrescentada à respectiva secção de $\omega$.

E um dos autores que se nomeia nas suas composições (32). Nelas surge associado a Santiago e a Lugo, onde terá exercido a sua actividade poética, nos fins do séc. XIII ou já no séc. XIV. Conservam-se ainda vários vestígios da linhagem dos Esauio, uma família da pequena nobreza galega sediada na região de Neda e ligada ao mosteiro de S. Martinho de Jubia, à qual pertenceria este trovador ( ${ }^{(33)}$.

\section{FERNAO DO LAGO (n. 74)}

Presente, apenas com uma cantiga de amor, no fim de um longo grupo de autores que aí concorrem, salvo raras excencões. com idêntico tipo de composicões (n.os 48 a 75). Os autores aue lhe estão próximos, à excencão de Airas Pais, surgem - tal como ele - apenas nesta zona do cancioneiro e somente com cantigas de amor. São eles: Golnarro, João de Cangas, Martim de Ginzo. Martim Codax e João de Reaueixo. Posterior, de aualaver modo, à feitura de $\omega$, as ilacñes a tirar da sua colocacão estão denendentes. tendo em conta a sua ligacão ineauívoca a um coniunto mais vasto de autores, da análise mais geral a fazer a esta zona do cancioneiro.

Fernanda Toriello identifica este autor com Fernand'Escanio (34). Em B e em V, os nomes de ambns, escritos pela mão do conista, aparecem no entanto claramente diferenciados. Como a própria autora

(28) Idem, ibidem, pp. 416-9.

(29) Henrique David, Os Portugueses nos Livros de «Repartimienton da Andaluzia (século XIII), Porto, 1986 (Separata da Revista da Faculdade de Letras, II Série, vol. I11). p. 19, n.o 35 .

(30) Inq., p. $358 b$.

(31) G. Tavani, Repertorio...., pp. 408 e 515.

(32) B 1604bis, ed. facs., p. 718; V 1137, ed. facs., p. 401.

(33) Fernanda Toriello, Fernand'Esquyo, Le poesie, Bari, 1976, pp. 30-5.

(34) Idem, ibidem, pp. 26-8. 
reconhece, seria preciso que a confusão se exercesse sobre quatro palavras, o que nos parece demasiado. Por outro lado, como ressalta da análise da colocação de ambos, apesar da sua proximidade pertencem a dois grupos com características diferentes. Nem saberíamos, finalmente, justificar - caso se tratasse apenas de um autor - a intrusão de João de Requeixo no interior da sua obra.

O topónimo Lago é comum a Portugal e à Galiza (35). Em Portugal existe uma família nobre com esse apelido. Um dos seus membros, Fernão do Lago, mostra-se muito activo na região do baixo Cávado, pelos meados do séc. XIII ( $\left.{ }^{36}\right)$. A ausência do patronímico nos cancioneiros e a sua ausência de $\omega$ levantam algumas reservas à sua identificação com o mesmo autor. Pelo nome e pelo tipo de composição - uma cantiga de romaria - pode tratar-se antes de um jogral galego. A falta de elementos mais seguros, a crítica tem-se dividido entre a atribuição de uma naturalidade galega ou portuguesa ( $\left.{ }^{37}\right)$. Quanto à sua cronologia, v. João de Cangas.

\section{FERNAO PADROM}

(n. $\left.{ }^{\circ} 22\right)$

Com três cantigas de amor, aparece colocado num grupo pouco homogéneo de autores, que surge após os clérigos presentes nesta secção do cancioneiro. Tendo em conta apenas este elemento, estaríamos perante um autor inserido no cancioneiro somente após a feitura de (.), quer nos fins do séc. XIII quer, mais provavelmente, na primeira metade do séc. XIV. Esta quase certeza cai no entanto por terra quando verificamos a sua presença em $\mathrm{A}$, precisamente com as mesmas composicões (38). Trata-se, portanto, de um autor já presente em $\omega$. Para o facto de as mesmas composições aparecerem posteriormente inseridas na seç̧ão das cantigas de amigo, aduzimos a hipótese levantada no caso de Afons'Eanes do Coton, ou seja, a de que este deslocamento teve a ver com as perturbações que a zona final da seccão das cantigas de amor de $\omega$ terá sofrido quando aí foram incorporados ncvos autores e, acrescente-se, numa altura em que também iá tinham sido acrescentados novos autores à secção das cantigas de amigo do mesmo cancioneiro. E pelo menos o que se pode inferir da sua colocação após o grupo dos clérigos.

Nada se sabe ainda acerca deste autor. Pela sua colocação Fernão Padrom deve ter vivido por volta de meados ou no terceiro quartel do séc. XIII.

\section{GALISTEU FERNANDES (n. ${ }^{\circ} 41$ e 67)}

Sobre os problemas levantados pela sua colocação em dois lugares deste acrescento à secção das cantigas de amigo, v. Airas Pais.

(35) Nunes, Amigo, III, p. 642.

(36) Inq., pp. 309b, 311b, 1430a, $1432 \mathrm{~b}$.

(37) Para a primeira, Nunes, Amigo, I, pp. 322; III, p. 642 e Tavani, Grundriss, fasc. 8, p. 20. Para a segunda, Manuel de Boaventura, Três trovadores medievais», $O$ Distrito te Braga, II, 1/2, Braga, 1963, pp. 203-7.

(38) A sua colocação neste cancioneiro pode ser vista no quadro representando a zona de intersecção entre $\omega$ e $\alpha$, em apêndice. 


\section{Revista de História das Ideias}

Nada se sabe de concreto acerca deste autor. Carolina Michaëlis aventou tratar-se de um tal Fernandes, natural da cidade leonesa de Galisteu ( ${ }^{39}$ ). A análise da estratigrafia desta zona da secção das cantigas dc amigo do cancioneiro permitir-nos-á uma aproximação à sua cronologia.

\section{GOLPARRO \\ (n. ${ }^{\circ}$ 69)}

Aparece apenas neste acrescento à secção das cantigas de amigo dc $\omega$ e somente com uma cantiga de amigo incompleta. Sobre a sua colocação, v. Fernão do Lago.

Nada se sabe deste autor que, pelo nome, era provavelmente um jogral. Pela referência, feita na sua composição, a um santo venerado em Tui, tem sido situado nessa região $\left({ }^{40}\right)$. Sobre a sua cronologia v. João de Cangas.

\section{D. GOMES GARCIA, abade de Valhadolide (n. ${ }^{\circ}$ 13)}

Integrado no grupo dos clérigos com uma cantiga de amor e uma cantiga de amigo. Como todos os autores da zona que analisamos, foi sem dúvida acrescentado a $\omega$ entre fins do séc. XIII e meados do séc. XIV. Os dados biográficos dele conhecidos concordam com esta pressuposição.

Personagem importante da corte catelhana na segunda metade do séc. XIII. Aparece, desde a década de setenta, associado ao infante D. Sancho, futuro Sancho IV de Castela, tendo participado a seu lado nos conflitos que o opuseram a seu pai, D. Afonso $\mathrm{X}$, nos últimos anos do seu reinado. Natural de Toledo aparece, pelo menos desde 1283, com o título de abade de Valhadolide e notário do reino de Leão, estando presente em muitos documentos do infante rebelde $\left({ }^{41}\right)$. Com a morte de $\mathrm{D}$. Afonso $\mathrm{X}$, mantem lugar proeminente na corte de seu filho, D. Sancho IV, até 1286, ano da sua morte (42). As crónicas posteriores seguidas por Mercedes Gaibrois, dão-no como tendo caído em desgraça na corte, após a sua missão diplomática junto do rei francês, nos fins de $1285{ }^{(43)}$. No entanto, um documento de Maio de 1286 , pouco anterior à sua morte, contradiz claramente esta versão dos acontecimentos. Com efeito, nessa data D. Sancho IV doa-lhe a várzea de Ardilla pelos serviços que lhe prestara e continuava a prestar. Mercedes Gaibrois, para não entrar em contradição, diz tratar-se apenas de uma trégua na desgraça do abade (44). Uma hipótese mais plausível é a de esta queda em desgraça do abade de Valhadolide ser uma construção posterior, romanceada, ligada aos Haro, que aparecem na crónica como seus grandes opositores.

\footnotetext{
(39) Michaëlis, CA, II, p. 624.

(40) Nunes, Amigo, I, pp. 325-6; Tavani, Grundriss, fasc. 8, p. 24.

(41) Antonio Ballesteros Beretta, Afonso $X$ El Sabio, Barcelona, 19842, pp. 736, 943, 971, 1017, 1056.

(42) Mercedes Gaibrois de Ballesteros, Sancho IV de Castilla, Madrid, 1922, I. particularmente cap. IV, p. 88 e $\mathbf{s s .}$

(43) Idem, ibidem, p. 92 e ss.

(44) Idem, ibidem, p. 102.
} 


\section{JOAO, jogral de Leão}

$$
\text { (n. 44) }
$$

Apenas com duas composições e agregado a mais três autores, separa as cantigas de amor das cantigas de amigo de um grupo mais alargado de autores, que se situam nesta zona do cancioneiro (n.os 29 . -43 e 48-73) com ambos os tipos de cantigas. As suas composições, um pranto pela morte de D. Dinis e um elogio ao novo soberano, D. Afonso IV, aparecem deslocadas no contexto onde se inserem, devendo pensar-se, para este caso, numa inclusão posterior à do grupo de autores acima referido.

A sua cronologia e naturalidade podem ser retiradas das suas cantigas e da respectiva rubrica atributiva. Jogral leonês, encontra-se na corte portuguesa pelo menos em 1325, ano da morte do monarca que lhe motivou a feitura de um pranto, tendo aí permanecido provavelmente uma dezena de anos ou mais. Com efeito, a referência, no elogio a D. Afonso IV, à morte de um urso pelo infante D. Pedro seu filho, nascido em 1320 , não deverá ser muito anterior nem posterior a 1335 para ser considerada feito digno de ser celebrado. Outra hipótese admissível é a de se ter apresentado na corte em épocas diferentes. Pode bem ter sucedido que, após a morte de $D$. Dinis, se tivesse agregado à corte do infante D. Pedro, conde de Barcelos, a quem elogia, na mesma composição, pela sua prodigalidade.

\section{JOAO AIRAS, burguês de Santiago} (n.:- 18 e 27)

Caso singular, o da colocação deste autor. As suas cantigas de amor e de amigo incluem-no num grupo de autore 3 situados entre o conjunto dos clérigos, que os antecedem, e o q:e parece ser um cancioneiro iniciado por Bernal do Bonaval (v. ficha deste autor). Situação que não teria nada de anormal se ele não aparecesse aí em dois lugares diferentes, no primeiro com as cantigas de amor, no segundo com as cantigas de amigo. De permeio, encontram-se oito autores com um número reduzido de composições. Várias hipóteses se podem pôr, à partida, na tentativa de encontrar resposta para esta anomalia. Atendendo ao volumoso conjunto de composições deste autor, mais de setenta nesta secção, pode admitir-se que o seu cancioneiro, previamente organizado por géneros poéticos, tivesse sido incluído (com excepção das cantigas de escárnio) nesta secção, após o grupo de clérigos que o antecede e quando não se tinham inserido ainda os autores que se lhe seguem. Esta ordenacão, isto é. a sequência natural das suas cantigas de amor e de amigo, poderia ter sido quebrada pelos acrescentos posteriores, nomeadamente por alguns trovadores portugueses que aparecem junto a si, como Rodrigu'Eanes d'Alvares, Rui Martins d'Oliveira e D. Pero Gomes Barroso, e ainda pelo deslocamento para esta zona de alguns autores presentes também em A ( $\mathrm{n}$ os $22-24$ e, eventualmente, n. ${ }^{\circ} 19$ ). Uma segunda hipótese é a da sua inclusão após a constituição desta zona do cancioneiro, tornando acrescidas as dificuldades de uma inserção num mesmo local das suas composições e obrigando, portanto, à sua colocação em dois locais diferentes. A hipótese da existência de diferentes tradições manuscritas e, consequentemente, de uma incorporação em momentos diferentes, parece mais frágil, tendo em conta a organização das suas composicões referidas atrás. Anote-se, finalmente, que as suas cantigas de escárnio, aparecendo na respectiva secção, estão na zona de $\omega$ e, logo, deslocadas. 
Não está ainda suficientemente definida a cronologia deste autor. As dificuldades têm residido na falta de documentação exterior ao cancioneiro e, por outro lado, na impossibilidade de datar com segurança as suas relações com outros autores, principalmente com João Vasques e com Pero Anes Marinho, com quem aparece relacionado. Como refere José Luis Rodriguez «Estas conexiones constituyen, por el momento, los únicos argumentos incontestables para demonstrar la pertenencia de Joan Airas al siglo XIII. Obviamente, todo lo que se haga por fijar la cronología de estos dos autores servirá para aproximarnos al burgués compostelano» (45). De João Vasques de Talaveira, sabe-se que esteve na corte de Afonso $\mathrm{X}$ onde se relacionou com outros autores aí estabelecidos (46). Em 1286 é ainda vivo, acompanhando D. Sancho IV de Castela a Baiona (47). Pero Anes Marinho é provavelmente seu contemporâneo (v. ficha deste autor). Perante a nova cronologia proposta para este autor, é possível trazer a de João Airas para a segunda metade do séc. XIII.

\section{JOAO BAVECA (n. ${ }^{\circ} 40$ e 62 )}

A sua colocação em dois lugares diferentes, e os problemas que levanta, é idêntica à de Airas Pais (v. ficha deste autor). As suas cantigas de escárnio e maldizer foram remetidas para a respectiva seccão. O facto de estas cantigas aparecerem inseridas na zona que pertence a $\omega$ é sinal evidente de inclusão posterior, situação que compartilha com os autores que o cercam. João de Gaia e João Airas de Santiago.

Os elementos biográficos disponíveis são os retirados das suas cantigas de escárnio e de maldizer e das de outros autores seus contemporâneos. As referências a Pero de Ambroa e à Balteira, por um lado, as tenções com Pedr'Amigo e o mesmo Ambroa, por outro, situam-no no grupo de trovadores e jograis agregados a Afonso $\mathrm{X}$ a partir de meados do séc. XIII. Em Portugal há alguns vestígios da existência de uma linhagem com esse apelido. Um Fernão Baveca, juntamente com seus filhos Afonso e Fernão Fernandes, aparece fugazmente no Livro de Linhagens do Conde D. Pedro, em virtude do seu casamento com Teresa Pires de Vides (48). E certamente o mesmo que, com seus irmãos, comete alguns atropelos no Julgado do Barroso, por volta de meados do séc. XIII (49). A colocação de João Baveca no cancioneiro, as suas relações com Amigo e Ambroa e a ausência de patronímico no seu nome, levantam, no entanto, algumas dúvidas em relação à sua consideração como trovador português. A maior parte da crítica tem-no na conta de jogral ou segrel galego $\left({ }^{50}\right)$. Segundo Lopez Ferreiro (51), seria um dos jograis agregados à hoste com que o magnate galego D. Rodrigo Gomes de Trastamara participou na reconquista.

(45) José Luis Rodriguez, El Cancionero de Joan Airas de Santiago. Edicion y Estudio, Santiago do Compostela, 1980, p. 17.

(46) Michaëlis, CA, II, pp. 119-23.

(47) Mercedes Gaibrois de Ballesteros, ob. cit., t. I, pp. 26, 52-3, 93-4 e CLXXI.

(48) LC 30BB5.

(49) Inq., 1518b.

(50) Cf. Tavani, Grundriss, fasc. 8, pp. 27-8.

(51) Antonio Lopez Ferreiro, ob. cit., V, p. 371. 


\title{
«Livro das Cantigas» do Conde D. Pedro
}

\author{
25. JOAO DE CANGAS \\ (n. ${ }^{\circ}$ 70)
}

Apenas com três cantigas de amigo, a sua situação nesta zona do cancioneiro é idêntica à de Fernão do Lago (v. ficha deste autor).

$\mathrm{O}$ seu apelido e a referência nas suas composições a S. Mamede do Mar, situam-no na região de Vigo, no sul da Galiza. A sua colocação na parte final das cantıgas de amigo não implica necessariamente a transposição da sua activıdade poética para fins do séc. XIII ou inícios do séc. XIV (52). Lembremos apenas que no vasto grupo de autores que comparecem nessa zona do cancioneiro com cantıgas de amigo estáo presentes, entre outros, Bernal do Bonaval, Juião Bolseiro, Pero d'Armea, Yedr'Amigo de Sevilha, João Baveca e os jograis Lopo e Lourenço, compositores do segundo e terceiros quarteis do séc. XIII. A ligaçao entre colocação e cronologia nos acrescentos às três secções de $\omega$ ja não possui, consequentemente, o mesmo grau de evidência. $\mathrm{Na}$ análise global a efectuar a esta zona da secção das cantigas de amigo, tentaremos situar melhor este e outros autores que partillham idêntica colocação.

\section{JOAO FERNANDES D'ARDELEIRO (n.9 78)}

Situado entre Estevão da Guarda e D. Mem Rodrigues de Briteiros, é o penúltimo trovador da zona do cancioneiro em análise, com uma cantiga de amor e uma cantiga de escárnio. Pela colocação e pelo tipo de composições, pode pensar-se numa incorporação tardia, provavelmente contemporânea da de Estevão da Guarda, que o antecede.

Da rubrica que antecede a sua cantiga de escárnio, consta que era escudeiro, com bens em Pavia, povoação pertencente actualmente ao concelho de Mora, no Alto Alentejo. A composição é dirigida contra um comendador, certamente da Ordem de Avis, a quem pertencia a povoação. Português ou não, a sua actividade ter-se-á desenvolvido em Portugal, onde há muito se encontrava, conforme se depreende da referência explícita existente na sua cantiga de amor.

\section{JOAO MENDES DE BRITEIROS (n. 4)}

Presente com seis cantigas de amor e três cantigas de amigo, no início deste acrescento (v. Afonso Pais de Braga).

Filho do trovador Mem Rodrigues, João Mendes de Briteiros (ou de Berredo) aparece na corte de D. Dinis a partir dos finais da década de oitenta (53), confirmando, por vezes, com o título de conselheiro régio, algumas dezenas de documentos, até ao ano de 1315. Por volta de 1290, casara com Urraca Afonso, filha bastarda de D. Afonso III e possuidora de vastos bens na região de Lamego (54). A partir de 1310 aparece, embora mais espaçadamente, em alguns documentos parti-

(52) Tavani, Grundriss, fasc. 8, p. 28. Na mesma obra, fasc. 6, p. 164, Tavani parece colocá-lo, bem como a Airas Pais, João de Requeixo, Martim de Caldas e Martim Campina, nos fins do séc. XIII.

(53) TT - Ch. Dinis, L. I, fl. 218.

(54) A. de Almeida Fernandes, Erraca (D.)», in Grande Enciclopedia Portuguesa e Brastleira, vol. XXXI, p. 545 . 


\section{Revista de História das Ideias}

culares, tratando da gestão de seus bens na Beira e no Minho. Ainda é vivo em meados de 1334, altura em que é resolvido um diferendo que o opôs ao bispo de Braga, D. Gonçalo Pereira (55). Foi sepultado, com sua mulher Urraca Afonso, no mosteiro de S. João de Tarouca.

\section{JOAO DE REQUEIXO$$
\text { (n. } 75 \text { ) }
$$

Ultimo autor a comparecer nesta zona do cancioneiro apenas com cantigas de amigo (sobre colocação e problemas que levanta ver Fernão do Lago).

O topónimo Requeixo é comum a Portugal e à Galiza. A referência, nas suas composições, à ermida de Faro, tem situado este autor na província de Lugo, Galiza, onde, além de uma ermida com este nome, existe uma povoação chamada Requeixo. Pelo nome e pelo tipo de composições - todas cantigas de romaria - tem sido colocado na categoria de jogral ${ }^{(56)}$. Quanto à sua cronologia, aguarde-se a definição da estratigrafia desta zona do cancioneiro (v., no entanto, João de Cangas).

\section{JOAO SERVANDO (n. ${ }^{\text {s }} 31$ e 50)}

Duas cantigas de amor e dezassete cantigas de amigo com uma inserção igual à de Bernal de Bonaval, autor que o antecede nos dois lugares que ocupa nesta secção (v. Airas Pais e Bernal de Bonaval). As suas quatro cantigas de escárnio aparecem na respectiva secção, mas incluídas na zona de $\omega$. A inserção tardia deste autor (e ainda de Lourenço, do conde D. Pedro e de João de Gaia) nesta zona, provocou uma cisão nas composições de Rui Pais de Ribela.

Nada se sabe acerca deste autor, para além das referências que podem ser retiradas das suas composições e da indicação do seu apelido. Considerado até há pouco tempo como toledano (57), esta naturalidade foi recentemente posta em causa com a descoberta de uma ermida dedicada a San Servando, em Santa Maria de Barxeles, Orense (58). A mesma autora, procurou integrá-lo no seu novo ambiente como «um poeta do meio, cantor «oficial» de San Servando, talvez adstrito a um mosteiro (Osera?) do qual a ermida dependeria» (59). Esta faceta de jogral regional é confirmada pelas suas composições. Note-se que, para além das suas cantigas de amigo, os personagens visados nas suas cantigas de maldizer são-nos dados a conhecer apenas através dessas mesmas cantigas. Uma situação com pouca probabilidade de se ter verificado caso este jogral tivesse frequentado a corte régia castelhana. A sua actividade poética deve datar, talvez, de meados ou da segunda metade do séc. XIII, altura em que as sátiras aos infanções tiveram alguma projecção no meio trovadoresco peninsular

(55) Jose Augusto Ferreira, Fastos Episcopais da lgreja Primacial de Braga, vol. I, Braga, 1928, p. 141 (nt. 1).

(56) Nunes, Amigo, I, p. 330, III, pp. 619-20; Tavani, Grundriss, fasc. 8, p. 28.

(57) Nunes, Amigo, I, p. 332; III, pp. 685-6.

(58) Elsa Gonçalves, ePressupostos históricos e geográficos à crítica textual no ambito da Ifrica medieval galego-portuguesa: (1) eQuel da Ribera»; (2) aA Romaria de San Servando», in Critique Textuelle Portugaise (Actes du Colloque, Paris 20-24 Out. 1981), Paris, 1986, pp. 45-49.

(59) Idem, ibidem, p. 48. 
A análise da estratigrafia da zona em que se insere poderá reforçar ainda mais a geografia e cronologia propostas.

$$
\text { 30. JOAO ZORRO }
$$

Integrado num longo grupo de autores que, nessa zona, concorrem apenas com cantigas de amigo, João Zorro apresenta aí uma cantiga de amor e dez cantigas de amigo. Sinal evidente de uma inclusão tardia, posterior, pelo menos, a esse grupo de autores.

A referência, nas suas composições, a Lisboa e a um rei de Portugal situam a sua actividade poética na corte portuguesa. A sua colocação sugere uma presença junto a D. Dinis ou mesmo D. Afonso IV, mas a sua condição de jogral, se tal for o caso, pode ter inibido a sua inclusão em $\omega$. Note-se, no entanto, que as cantigas de amigo parecem ter adquirido algum significado, em termos numéricos, na corte portuguesa, apenas a partir dos finais do séc. XIII. O seu apelido não é desconhecido em Portugal ( ${ }^{60}$ ).

\section{JUIAOO BOLSEIRO (n. ${ }^{\circ} 33$ e 54)}

Colocação idêntica à de Airas Pais e Bernal de Bonaval (v. fichas respectivas). A única cantiga de maldizer que possui, uma tenção com João Soares Coelho sobre a ama por este celebrada, aparece junto das suas cantigas de amigo (n. $0^{\circ}$ ). Está ainda presente em A, mas aqui por intermédio de Mem Rodrigues Tenoiro, numa tenção em que este simula uma briga com Bolseiro.

Das tenções com Tenoiro e Coelho deve retirar-se a indicação de uma actividade poética ocorrida por volta de meados - ou na segunda metade - do séc. XIII. Não há elementos concretos que abalizem uma sua presença em Portugal. E mais admissível ter poetado no círculo cortesão de Afonso $X$, onde se encontrava Mem Rodrigues Tenoiro e por onde passou também João Soares Coelho antes de se acolher à corte de Afonso III de Portugal. A condição de vilão que lhe atribuem ambos os trovadores mencionados indica tratar-se de um jogral. Quanto à sua naturalidade, vejam-se as indicações retiradas da análise global do grupo de autores em que aparece integrado.

$$
\begin{aligned}
& \text { 32. LOPO, jogral } \\
& \text { (n. } 42 \text { e 66) }
\end{aligned}
$$

Colocação idêntica à de Airas Pais e Bernal de Bonaval (v. fichas respectivas).

As críticas que lhe são feitas por Martim Soares, trovador português da primeira metade do séc. XIII, e uma ou outra referência das suas composições, colocam-no no mesmo período e com assento na corte de Fernando III ( ${ }^{(1)}$.

$$
\begin{aligned}
& \text { 33. LOURENÇO, jogral } \\
& \text { (n.: } 39,43 \text { e 68) }
\end{aligned}
$$

Colocação idêntica à de Airas Pais e Bernal de Bonaval (v. fichas respectivas). Sobre as suas cantigas de escárnio, v. João Servando. Os

(80) Inq., pp. 79b, 522ab, 1366b; TT - Santa Cruz, m. XIX, doc. 17.

(61) Nunes, Amigo. I, pp. 194-5. 
outros locais em que surge em $\omega$ estão dependentes dos trovadores com quem manteve relações poéticas através de tenções.

E a partir destas tenções, e de uma ou outra composição de autores com quem entrou em contacto, que têm sido definidos os principais traços biográficos deste jogral ${ }^{\left({ }^{62}\right)}$. Activo na segunda metade do séc. XIII, acorreu à corte castelhana vindo de Portugal, segundo se depreende da sua tenção com João Vasques de Talaveura. Os trovadores portugueses com quem se relaciona, João Peres de Aboim, João Soares Coelho, Rodrigo Eanes Redondo e João Garcia de Guilhade, estiveram todos, mais ou menos esporadicamente, fora de Portugal, dificultando a definição de uma geografıa e cronologia seguras para os debates que os opuseram a este jogral $\left.{ }^{63}\right)$. Considerado unanimemente como portuguès, Lopez Ferreiro procurou identificá-1o com um cantor da catedral de Santiago, ao qual, em 1245, o cabido compostelhano aforara a herdade de Sá, na Correlhã, perto de Ponte de Lima, donde seria natural $\left.{ }^{64}\right)$.

\section{MARTIM DE CALDAS (n. ${ }^{\circ}$ 57)}

Sete cantigas de amigo com colocação idêntica à de Fernão do Lago (v. ficha respectiva).

O topónimo Caldas é comum a Portugal e à Galiza. As suas composições não contêm, todavia, quaisquer elementos que nos levem a optar por uma ou por outra naturalidade. Tem sido colocado na categoria de jogral (65). Sobre os cuidados a ter na associação entre colocação e cronologia, v. João de Cangas.

\section{MARTIM CAMPINA (n. 55)}

Duas cantigas de amigo com colocação idêntica à de Fernão do Lago (v. ficha respectiva).

Do ponto de vista biográfico, a situação é idêntica à do autor anterior, Martim de Caldas ( ${ }^{(6)}$.

\section{MARTIM CODAX}

(n. 72 )

Sete cantigas de amigo com colocação idêntica à de Fernão do Lago (v. ficha respectiva). As composições deste autor foram ainda preservadas num pergaminho - Pergaminho Vindel, do nome do livreiro madrileno Pedro Vindel, que o descobriu -, conservado actualmente na Pierpont Morgan Library, em Nova Iorque, contendo não apenas o texto poético mas também a notação musical das referidas cantigas.

Nada se sabe de concreto acerca deste autor. No entanto, a tradição manuscrita das suas composições, por um lado, as referências geográficas aí também existentes, por outro, permitem um enquadramento mínimo da sua actividade. Com efeito, a existência de $\mathbf{N}$, datado

(62) G. Tavani, Lourenço. Poesie e tenzont, Modena, 1964, pp. 16-26.

(63) Ver, no entanto, trajectória proposta por G. Tavani na obra anterior.

(64) Antonio Lopez Ferreiro, ob. cit., V, p. 377.

(65) Nunes, Amigo, I, pp. 232-3; Tavani, Grundriss, fasc. 8, p. 38.

(66) Nunes, Amigo, I, p. 233. 


\section{«Livro das Cantigas» do Conde D. Pedro}

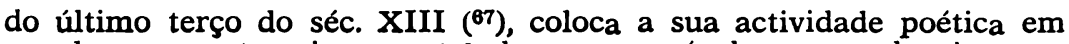
meados ou no terceiro quartel do mesmo século, provando algo que já presumiramos: a divergência entre colocação e cronologia no caso dos autores que surgem nesta zona do cancioneiro, quer com cantigas de amor e cantigas de amigo quer, como é o caso, apenas com cantigas de amigo (v. João de Cangas). Quanto à naturalidade de Martim Codax, as referèncias a Vigo situam-no nesta região do Sul da Galiza. Tem sido colocado na categoria de jogral $\left({ }^{68}\right)$.

\section{MARTIM DE GINZO}

$$
\text { (n.9 71) }
$$

Colocado entre João de Cangas e Martim Codax, com oito cantigas de amigo (v. Fernão do Lago).

Nada se sabe de concreto aeste autor, que tem sido considerado como jogral ( $\left.{ }^{(6 y}\right)$. Os toponimos de Ginzo e Sobral, este presente nas suas cauugas de amigo, sao comuns à Galiza e a rortugal (10). As satıras de João Garcıa de Guilnade a um jogral de nome Martım, näo constıtuem, dada a existéncia de várıos nos cancioneiros e mesmo fora deles, elemento seguro pra pensarmos tratar-se de Martım de Ginzo ("1). Apesar de natural de uma região proxıma da povoação portuguesa de Ginzo, João de Gulhade esteve tambem fora de Yortugal, como se depreende das suas composıçöes. Sobre a sua cronologia, convêm ter presente o que se disse em relação a João de Cangas.

\section{MARTIM MOYA * (n.: 7 e 9)}

Integrado, por duas vezes, no grupo de clérigos que surge quase no início deste acrescento à secção das cantigas de amigo de $\omega$. Apenas

(67) Manuel Pedro Ferreira, $O$ Som de Martim Codax. Sobre a dimensão musical da lírica galego-portuguesa (séculos XII-XIV), Lisboa, 1986, p. 73.

(68) Tavani, Grundriss, fasc. 8, p. 38 e bibliografia ai citada.

(69) Nunes, Amigo, I, p. 311; Tavani, Grundriss, fasc. 8, p. 39.

(70) Nunes, Amigo, III, pp. 594-5.

(71) António da Costa Lopes, A naturalidade portuguesa do jogral Martim de Ginzo. Anotaçóes críticas», Distrito de Braga, II, 3 e 4 (1964), p. 178 e ss., onde o autor resume a história dessa identificação, iniciada em 1949.

(*) Luciana Stegagno Picchio na edição da obra deste autor, já citada, terminava a digressão sobre o seu nome (pp. 23-32) com a indicação de que o problema permanecia em aberto. Sem termos pretensōes a fechá-lo, gostaríamos apenas de justificar a legitimidade Ja utilização de ambos os apelidos, partindo dos argumentos desenvolvidos pela referida autora.

O seu nome comparece por tres vezes no interior de composiçōes dos cancioneiros V e B: como Martim Moya (ou Moia, em V) numa composiçåo de A. Gomes, jogral de Sarria, e também numa cantiga do próprio autor, em que ele se nomeia a si próprio; como Martim Moxa, numa composiçăo de Joåo de Gaia, datável de c. 1330 . Se os cancioneiros não nos enganam, a conclusăo só pode ser a de que o autor foi conhecido pelos dois apelidos ainda durante o perfodo de florescimento desta manifestação cultural, utilizando-se a grafia Moya (ou Moia) na segunda metade do séc. XIII, altura em que desenvolveu a sua actividade em Castela, e preferindo-se a grafia Moxa no segundo quartel do sec. XIV em Portugal, onac a composiğ̊o de Joăo de Gaia foi produzida. Supomos que esta divergencia se ficou a dever aos imponderáveis da tradiçăo manuscrita. Lembremos, antes de mais, que o autor em análise aparece pela primeira vez em $A$. Infelizmente, pela falta de rubricas atributivas neste cancioneiro e também porque o próprio autor năo se nomeia nas 5 cantigas de amor af́ 


\section{Revista de História das Ideias}

com cantigas de amor e de escárnio, essa inserção coaduna-se perfeitamente com um núcleo de autores onde não é visível qualquer organização por géneros poéticos. Um único problema subsiste: a inclusão, na sua obra, de um outro autor, Rui Fernandes de Santiago, acabando por dividi-la por dois locais diferentes. Circunscrevendo-nos tão somente à análise desta zona do cancioneiro, pensaríamos de imediato numa incorporação tardia de Rui Fernandes. O problema ganha no entanto uma nova dimensão, quando verificamos que ambos os autores, Martim Moya e Rui Fernandes, comparecem, pela mesma ordem, no fim de A ( $\left.{ }^{72}\right)$, e que desta colocação há ainda alguns vestígios na secção das cantigas de amigo. Com efeito, tanto de um como de outro constam, nesta secção, cantigas de amor presentes em A (73). Estamos, portanto, perante um deslocamento idêntico ao verificado no caso de Fernão Padrom (v. ficha respectiva). Aqui, porém, além de cantigas de escárnio temos cantigas de amor, ausentes de A, enquanto o mesmo $\mathrm{A}$ terá conservado, por sua vez, cantigas de amor deste autor, que não aparecem nesta secção das cantigas de amigo. A hipótese mais plausível é a da existência, para este autor, de duas tradições manuscritas -- uma ligando-o a $\omega$, a outra ao grupo de clérigos da secção das cantigas de amigo - , reunidas no momento da incorporação de novos autores na sequência da secção das cantigas de amor de $\omega$ (v. Afons'Eanes do Coton). A sua colocação em dois locais diferentes desta zona da secção das cantigas de amigo encontrar-se-ia assim justificada. Sendo, no entanto, um dos últimos autores de $A$, ou seja, da secção de cantigas de amor de $\omega$, pode também ter-se verificado uma incompleta sistematização, neste cancioneiro, de uma única tradição manuscrita anterior das suas composições.

Presente em $\omega$, a sua actividade poética deve situar-se, o mais tardar, no terceiro quartel do séc. XIII. A análise da sua obra permitiu colocar este clérigo, castelhano ou aragonês, no âmbito da corte de Afonso X (74).

presentes, nada podemos inferir acerca do seu nome. Resta-nos a tradição manuscrita que - liga a $\alpha$, cuja confeç̧ăo se deve situar em Portugal perto de meados do séc. XIV. Al a opção parece ser claramente a forma Moxa. Presente, como vimos, na composiçăo de João de Gaia, mas também nas rubricas atributivas de $V$ e $B$.

A resposta a este problema está, quanto a nos, na Galiza. Com efeito, o facto do autor nos aparecer tambem incluído num grupo de clérigos, quase todos galegos, leva-nos a avançar com a hipbtese de o seu conhecimento em Portugal se ter dado por intermédio da Galiza, onde terá sido copiada pelo menos parte das suas composiçóes. Como já assinalou Picchio, pode ter-se verificado uma galeguização do seu apelido em eMoxa», por intermédio da forma «Moja», correspondente, na grafia do tempo, a «Moia». Esta possibilidade é reforçada, como veremos, pelo facto das parcelas mais homogéneas (do ponto de vista da colocação) do acrescento que analisaremos estarem, tambem elas, associadas a Galiza. A recepcão em Portugal das suas composiçóes incorporaria já essa modificą̧̆o nas rubricas atributivas, como se depreende da composiçăo de Joăo de Gaia e das proprias rubricas de Colocci. Uma ultima consequência desta hipótese, se ela $\epsilon$ correcta, $\in$ a do conhecimento do cancioneiro dos clérigos em Portugal antes de 1330, altura em que terá sido composta a satira de Jošo de Gaia.

Neste contexto, a um portuguess nåo ficaria mal o tratamento do autor por Moxa. Optamos, porém, por Moya por nos parecer a forma mais corrente na segunda metade do sấc. XIII em Castela, altura e lugar em que terá vivido o compositor.

(72) $V$. quadro da zona de interseç̧⿰丿乛⿱㇒⿵冂卄丷 entre $\omega$ e $\alpha$, em apendice.

(73) Sobre os problemas de atribuiçáo levantados pela obra de Martim Moya, v. Luciana Stegagno Picchio, ob. cit., pp. 53-64.

(74) Idem, ibidem, pp. 23-51. 


\section{«Livro das Cantigas» do Conde D. Pedro}

\section{MARTIM PADROZELOS \\ (n. 65$)$}

Com nove cantigas de amigo e uma cantiga de amor, surge no meio de um vasto grupo de autores presentes nessa zona apenas com cantigas de amigo. A sua cantiga de amor lança algumas dúvidas em relação à sua ligação, em termos de colocação, com esses autores, podendo pensar-se talvez numa inserção ainda mais tardia (v., no entanto, Fernão do Lago).

Nada se sabe ae concreto acerca deste autor. Os topónimos Valongo, este citado nas suas cantıgas de amigo, e Padrozelos sao comuus a rortugal e à Galıza ( ${ }^{(5)}$. L lavani, nảo sabemos porque motıvo, considera-o portuguës e, provaveımente, dos tinais do sec. Xill ( ${ }^{(6)}$ ). A sua colocaçao nao nos da quaısquer certezas quanto ao periodo em que situar a sua actıvidade poetica (v. João de Cangas).

\section{MARTIM PERES ALVIM \\ (n. 28$)$}

O primeiro de um grupo de autores apenas com cantigas de amor na zona do cancioneiro em que se insere. Todavia, os autores que o seguem reaparecem posteriormente, com cantigas de amigo, na mesma secção do cancioneiro. Podemos supor uma incorporação tardia deste trovador, já que, por outro lado, nada o liga também aos autores que 0 antecedem.

Filho de Pero Soares Alvim, Martim Peres ligou-se aos Ribeiro pelo seu casamento com Margarida Peres, filha de Pero Afonso Ribeiro. Em 1292 está presente ao pedido de legitimação de um fılho bastardo do mesmo Pero Afonso (77), mas deve ter-se ausentado de Portugal pouco depois, porquanto no ano seguinte recebe soldada de $D$. Sancho IV de Castela (78). Nos inícios do séc. XIV é um dos vassalos do infante D. Afonso, futuro D. Afonso IV, tendo-o certamente apoiado nos conflitos que o opuseram a seu pai D. Dinis. Em 1326 ainda é vivo, testemunhando uma ordenação da Ordem de Cristo relativa à Universidade de Coimbra ${ }^{(79)}$.

\section{MEM RODRIGUES DE BRITEIROS (n. ${ }^{\circ} 3$ e 79$)$}

Aparece em dois locais diferentes, no início e no fim deste acrescento. No início, entre Afonso Pais de Braga e João Mendes de Briteiros, seu filho, com uma cantiga de amor ( ${ }^{80}$ ); no fim, com duas cantigas de escárnio e de maldizer e precedido por Estevão da Guarda e João Fernandes d'Ardeleiro ( ${ }^{81}$. Dado o carácter anómalo desta colocação, e não havendo engano nas rubricas que em B lhe atribuem

(75) Nunes, Amigo, I, pp. 234-6.

(76) Tavani, Grundriss, fasc. 6, p. 162; fasc. 8, pp. 39-40.

(77) TT - Ch. Dinis, L. II, fl. 27.

(78) Mercedes Gaibrois de Ballesteros, ob. cit., I, p. LIV.

(79) Chartularium Universitatis Portugalensis, ed. de Artur Moreira de Sa, I, Lisboa, 1966, doc. 72 .

(80) Em V, $\in$ atribuida a seu filho Joảo Mendes de Briteiros.

(81) Em V, a falta de rubrica atributiva, as composições são atribuldas ao autor anterior, Joåo Fernandes d'Ardeleiro. 


\section{Revista de História das Ideias}

estas composições, pode pressupor-se uma colocação tardia, obedecendo a espaços encontrados disponíveis.

Rico-homem português da segunda metade do séc. XIII, Mem Rodrigues é filho de um outro trovador, Rui Gomes de Briteiros, cuja acçáo a favor do conde de Bolonha foi já posta em relevo por Carolina Michaëlis ( ${ }^{82}$. Com uma presença esporádica na corte de Afonso III na década de cinquenta, confirma, entre 1261 e 1288, grande número de documentos régios, com a designação de tenente da Maia. Entre 1291 e 1294, pelo menos, encontramo-1o em Castela, ao serviço de D. Sancho IV (83). Kegressa pouco depois à corte portuguesa, aparecendo como substituto do mordomo régio em vários documentos dos finais do séc. Xi11. Leve ter morrido pouco depois de Fevereiro de 1304, data do último documento que subscreve na corte de D. Dinis $\left(^{\left({ }^{4}\right)}\right.$.

\section{MENDINHO $\left(n^{\circ} 1\right)$}

Primeiro autor deste acrescento à secção das cantigas de amor de $\omega$. Dada a sua condição provável de jogral, é pouco natural que fizesse parte da primeira grande compilação cujo tom aristocrático é evidente. Na secção das cantigas de amigo, a sucessão natural dos trovadores dessa compilação quebra-se no autor que o antecede, Vasco Rodrigues de Calvelo, ao mesmo tempo o antepenúltimo da secção das cantigas de amor ${ }^{85}$ ). Situação paradoxal. Ligado, pela colocação e pelo respeito à divisão por géneros poéticos, aos trovadores que o antecedem, tudo o aproxima, no entanto - condição social, naturalidade, tom popular da sua única cantiga de amigo - , de um longínquo grupo de autores que quase «fecham» este acrescento. Um jogral entre clérigos e trovadores, isolado. "E cercaron-mi as ondas do alto mar/ non ei barqueiro, nem sei remar....».

Pela referência à ermida de S. Simão, Menendez Pidal situou-o na região de Vigo, no Sul da Galiza $\left({ }^{86}\right)$.

\section{NUNO PORCO \\ (n.o 47)}

Com uma cantiga de amigo, é o primeiro de um longo grupo de autores (n. ${ }^{\circ}$ 47-75), quase todos com o mesmo tipo de composições, ocupanılo boa parte da segunda metade deste acrescento à secção das cantigas de amigo. B atribui-lhe ainda um fragmento de uma cantiga de amor presente na respectiva secção desse cancioneiro e também em A. $O$ confronto entre A e B, nesta zona da secção das cantigas de amor, levanta no entanto algumas dúvidas em relação a esta atribuição.

(82) Michaëlis, $C A$, II, pp. 337-8.

(83) Mercedes Gaibrois de Ballesteros, ob. cit., I, pp. CXLVIII, XXXIX, LXIV; III, doc. 371 .

(84) TT - Ch. Dinis, L. III, fl. 30v.

(85) Ver o quadro da zona de intersecçio entre $\omega$ e $\alpha$, em apendice.

(86) Pidal, Poesia, p. 118. 
«Livro das Cantigas» do Conde D. Pedro

\begin{tabular}{c|l|l|l} 
A & B & \multicolumn{1}{c}{ V } & \multicolumn{1}{c}{ AUTORES (segundo B) } \\
\hline 64 & 175 & & AIRAS CARPANCHO \\
65 & 177 & & \\
66 & 178 & & \\
67 & 179 & & \\
& 180 & & NUNO RODRIGUES DE CANDAREY \\
68 & 181 & & \\
69 & 181 bis (1451) & $(1061)$ & (JOAO DE GAIA) \\
70 & 183 & & NUNO PORCO \\
71 & 184 & & NUNO FERNANDES TORNEOL \\
72 & 185 & & \\
etc. & etc. & &
\end{tabular}

Com efeito, em A, ao autor das cantigas 64-67, Airas Carpancho segundo $B$, segue-se, na página seguinte, um novo grupo de duas cantigas (68 e 69) antecedidas por uma iluminura. Indicando esta, por norma, mudança de autor, estaríamos assim perante um novo autor com duas composições. Ao reverso desta página, deixado em branco, e à folha seguinte, cortada sem que possamos saber o que conteria, sucedem-se, após iluminura, as cantigas 70 e seguintes, pertencentes a um novo autor, Nuno Fernandes Torneol, segundo B. Ora, em B, mantendo-se a mesma sequência para Airas Carpancho e para Nuno Fernandes Torneol, como vimos, as composições 68 e 69 de A (181 bis e 182 de B) são atribuídas a dois autores diferentes, Nuno Rodrigues de Candarey e Nuno Porco, sendo ainda acrescentadas duas novas composições, as 180 e 181, atribuídas ao primeiro destes dois autores e sem que em $\mathrm{A}$ houvesse espaço para elas poderem ter sido aí incluídas. Assinale-se, finalmente, que em B e V uma variante da cantiga 68 de A é atribuída a João de Gaia, um trovador do séc. XIV inserido na secção das cantigas de escárnio e de maldizer. Mais fiel a A, Carolina Michaëlis atribui as cantigas 68 e 69 a um mesmo autor, Nuno Rodrigues de Candarey (87). G. Tavani e Jean Marie d'Heur, apoiando-se na atribuição de B, dividiram-nas por Nuno Rodrigues de Candarey e Nuno Porco, respectivamente (88). $\mathrm{O}$ acrescento de novas composições e a possibilidade de atribuição de uma das composições já existentes a João de Gaia, indicam que $\omega$ foi provavelmente reformulado nesta zona, entre os fins do séc. XIII e meados do séc. XIV. A incorporação de Nuno Porco pode ter sido um dos motivos das contradições verificadas entre A e B, mas, neste caso, teríamos que admitir que $B$ não resolveu da melhor maneira o problema das atribuições. A ter-se verificado, não seria a única inserção de um autor do acrescento às cantigas de amigo na secção das cantigas de amor de $\omega$ (v. Pero Garcia de Ambroa e Sancho Sanches).

Nada se sabe de concreto acerca deste autor. Pelo nome, pela presença no acrescento à secção das cantigas de amigo e pelo tom popular da sua cantiga de amigo, parece tratar-se de um jogral. Tavani, apoiado talvez na hipótese avançada por C. Michaëlis - de que Nuno

(87) Michaëlis, CA, I, pp. $145-7$.

(88) Tavani, Repertorio...., p. 472; D'Heur, eNomenclature...», p. 48. 
Porco seria um jogral ao serviço dos senhores de Candarey -, considera-o português $\left.{ }^{89}\right)$.

\author{
44. NUNO TREZ \\ (n. 58$)$
}

As suas únicas composições, quatro cantigas de amigo, surgem também integradas no grupo de autores com o mesmo género poético neste acrescento ( $v$. Fernão do Lago). Antecedem-no três autores, Martim Campina, Pero Meogo e Martim de Caldas, igualmente presentes nesta zona apenas com cantigas de amigo.

$\mathrm{O}$ nome e a referência a $\mathrm{S}$. Clemenço do Mar situam-no na região de Pontevedra, no sul da Galiza $\left({ }^{90}\right)$. Pelo tom popular das suas únicas composições - quatro cantigas de romaria - tem sido considerado como jogral ( ${ }^{(91)}$. Sobre a ligação entre colocação e cronologia, v. João Cangas.

\title{
45. PAI CALVO \\ (n..$^{\circ}$ 64)
}

Apenas com duas cantigas de amigo, insere-se num grupo de autores com o mesmo tipo de composições, na parte final deste acrescento (v. Fernão do Lago).

Nada se sabe de concreto acerca deste autor. Vários Pai Calvo são mencionados nas inquirições de 1220 e 1258 (92), mas sem qualquer indicação sobre uma possível actividade poética e musical. G. Tavani, sem aduzir razões, considera-o português e provavelmente dos finais do séc. XIII ou inícios do séc. XIV (93). Sobre as dificuldades em fixar cronologicamente este autor, ver o que dissemos sobre João de Cangas.

\section{PAI DE CANA, clérigo

$$
\text { (n. }{ }^{\circ} \text { 15) }
$$

Integrado, com duas cantigas de amigo, no grupo de clérigos que quase inicia este acrescento à seç̧ão das cantigas de amigo de $\omega$ (v. Airas Nunes).

António Lopez Ferreiro identificou-o com um clérigo compostelano de meados do séc. XIII, filho ou irmão de D. Pedro Arias da Cana, burguês de Santiago, aventando ainda a hipótese de Mor da Cana, referida por João Airas de Santiago, ser irmã do autor ( ${ }^{(4)}$ ).

\section{PEDR'AMIGO DE SEVILHA

$$
\text { (n. }{ }^{\circ} 37 \text { e 60) }
$$

Colocação, igual à de vários autores, em dois lugares diferentes deste acrescento e respeitando a divisão, aí verificada, entre cantigas de amor e cantigas de amigo (v. Airas Pais e Bernal do Bonaval). As

(89) Tavani, Grundriss, fasc. 6, pp. 150-1; fasc. 8, p.43; Michaëlis, CA, II, p. 343.

(90) Alvaro Júlio da Costa Pimpão, História da Literatura Portuguesa, Idade Média. Coimbra, 1959², p. 128 (nt. 21); Nunes, Amigo, I, pp. 236-7.

(91) Ver Tavani, Grundriss, fasc. 6, p. 151; fasc. 8, p. 43.

(92) Inq., pp. 49b, 70b, 356a, 596a, 643a.

(93) Tavani, Grundriss, fasc. 6, p. 162; fasc. 8, p. 43.

(94) Antonio Lopez Ferreiro, ob. cit., p. 377. 


\section{«Livro das Cantigas» do Conde D. Pedro}

suas cantigas de escárnio surgem na respectiva secção, correctamente colocadas, embora em dois lugares diferentes, no princípio e no fim do acrescento a essa mesma secção.

A partir das suas cantigas de escárnio e de maldizer, pelos temas tratados e pelos compositores com quem se relacionou, podemos situá-lo no círculo de trovadores e jograis que rodearam Afonso $\mathrm{X}$ na segunda metade do séc. XIII. Pela cronologia proposta para algumas dessas composições ( $\left.{ }^{95}\right)$, o seu período de maior actividade poética c musical ter-se-á verificado nas décadas de 60 e 70 do referido século. Os vários documentos que o referem, estendendo-se de 1260 a 1302, confirmam esta cronologia e permitem-nos esboçar, a traços largos, as suas andanças. Clérigo galego, Pedr'Amigo terá mantido contactos com a corte régia durante as décadas atrás mencionadas e, posteriormente, integrou-se no clero da catedral de Salamanca. Deve ter morrido pouco depois de 1302, altura em que, como cónego de Salamanca, manda redigir o seu testamento ${ }^{(96)}$.

\section{PEDR'EANES SOLAZ (n.9 61)}

Pertencem-lhes duas cantigas de amor, inseridas no meio de um grande grupo de autores apenas (salvo raras excepções) com cantigas de amigo nessa zona. $O$ desrespeito pela organização por géneros poéticos verificada na segunda metade deste acrescento é, desde logo, um indício de uma inclusão mais tardia do que a da zona em que se incorpora. Não se trata porém de um autor do séc. XIV, como se poderia pensar. Se olharmos para a parte final da secção das cantigas de amor de A, vemos que é um dos autores aí presentes com quatro cantigas de amor, duas das quais são precisamente as que encontramos no acrescento em análise. O facto de uma destas composicñes. Non est a de Nogueyra, apresentar leituras divergentes em A e BV, levou iá G. Tavani a concluir pela existência, para esta cantiga, de uma dupla tradição manuscrita (97). Aparece igualmente com três cantigas de amigo na respectiva seccão de $\omega$, incorporadas correctamiente na parte final dessa mesma secção ( $\left.{ }^{98}\right)$. Estamos portanto. mais uma vez, perante um caso de deslocamento parcial de composições da seccão das cantigas de amor de $\omega$ para o acrescento à sua seccão de cantigas de amigo (v. Afons'Eanes, Fernão Padrom e Martim Moya).

A colocação na parte final de $\omega$, não só na secção das cantigas de amor, mas também na das cantigas de amigo, remete a sua actividade para os meados ou terceiro quartel do séc. XIII. Pela referência, numa das cantigas de amor, a uma freira de Nogueira, tem-lhe sido atribuída como naturalidade, a região de Pontevedra, onde ficava 0

(85) Giovanna Marroni, ele poesie di Pedr'Amigo de Sevilhaw, Annali dell'Istituto Universitario Orientale di Napoli-Sezione Romanza, X, Nápoles, 1968, pp. 194-210.

(96) Idem, ibidem, pp. 210-24. Cf. A.J. da Costa Pimpão, ob. cit., pp. 127-8, nt. 18.

(97) G. Tavani, Poesia del Duecento...., pp. 235-250. O autor aproveitou também, na parte final do seu estudo sobre esta composição, para fazer algumas reflexões pertinentes sobre as relaçóes entre A e BV. Como sugerimos na nt. 30 do nosso trabalho, o alargamento do campo de observação proporcionado pelo novo enquadramento que propomos para a resolução deste problema poderá, eventualmente, possibilitar conclusōes seguras num futuro próximo.

(88) A sua colocação em $\omega$ pode ver-se no quadro da zona de intersecção entre $\omega$ e $\boldsymbol{\alpha}$. em apendice. 


\section{Revista de História das Ideias}

mosteiro com o mesmo nome ( $\left.{ }^{(9)}\right)$. $\mathrm{O}$ apelido, aliado à textura popular das suas cantigas de amigo, valeram-lhe ser incluído na categoria de segrel ou jogral (100).

Em 1268 morria, em Burgos, uma D. Urraca, mulher de um Pedro Anes, jogral (101). A identificação deste jogral com Solaz, transformando-o portanto, num autor castelhano, para além de concordar com a cronologia proposta pela sua colocação em $\omega$, permitiria compreender melhor os castelhanismos descobertos nas suas composições (102).

\section{PERO (GARCIA) DE AMBROA (n. ${ }^{\circ}$ 63)}

Correctamente inserido, com uma cantiga de amigo, no grupo de autores que quase fecham este acrescento com igual tipo de composições. As suas cantigas de escárnio foram deslocadas para a respectiva secção, aparecendo dispersas entre a parte final de $\omega$ e seu acrescento nessa mesma secção e entre autores presentes também no acrescento à secção das cantigas de amigo. $O$ único óbice a esta colocação, que o faz emparceirar com a maior parte dos autores presentes na segunda metade do acrescento em análise, é o aparecimento, na secção das cantigas de amor de $\omega$, de uma sua cantiga de amor. Pensamos estar aqui, atendendo à colocação da sua restante obra, perante uma incorporação tardia, em $\omega$, dessa mesma composição. Incorporacão tanto mais facilitada quanto se tratava apenas de uma cantiga com possibilidades, portanto, de ser facilmente transcrita num qualquer espaço deixado em branco. Uma situação semelhante à de Nuno Porco, se as divergências entre $\mathrm{A}$ e $\mathrm{B}$, neste caso, não a tornassem mais complexa. Note-se, finalmente, estarmos perante dois autores presentes nesta secção apenas com uma cantiga de amor (v. também Sancho Sanches).

C. Michaëlis, a partir das muitas cantigas de maldizer em que Ambroa participa, como autor ou como personagem visada, pôde já definir o perfil e a cronologia deste autor (103). Natural de Ambroa, no norte da Galiza, o jogral ou segrel Pero Garcia teria frequentado já a corte de Fernando III e ainda a de seu filho Afonso X, nos primeiros anos do seu reinado. Era provavelmente vassalo de D. Rodrigo Gomes de Trastamara, e neste caso seria segrel, se o pudermos identificar com o D. Pedro Garcia de Ambroa que é mencionado, em 1237, em documentos de D. Rodrigo (104).

\section{PERO ANES MARINHO (n. ${ }^{\circ}$ 16)}

Incluído na parte final do grupo de clérigos presentes no início deste acrescento. A sua colocação parece estar dependente da de João Arras Santiago. E o que se pode depreender, pelo menos, da rubrica que

(89) Pidal, Poesia, p. 119; Tavani, Grundriss, fasc. 8, p. 46.

(100) Pidal, Poesia, p. 118; Erilde Reali, en Canzoniere di Pedro Eanes Solazw, Annali dell'Istituto Universitario Orientale di Napoli-Sezione Romanza, IV, 2, Nápoles, 1962, p. 169.

(101) Antonio Ballesteros Beretta, ob. cit., p. 356.

(102) Michaëlis, CA, II, p. 450; Pidal, Poesia, pp. 119-20.

(103) Michaëlis, CA, II, pp. 531-45.

(104) Antonio Lopez Ferreiro, ob. cit., pp. 372, nt. 2. 


\section{«Livro das Cantigas» do Conde D. Pedro}

acompanha a sua única composição, uma cantiga de amor: «Esta cantiga fez Pero Anes Marinho filho de Johan Rodrigues de Valadares per salvar outra que fez Johan Ayras de Santiago que diz asi comenzo: Dizen amigo que outra senhor queredes vós sen meu grado filhar» (105). Entre um e outro encontramos apenas Sancho Sanches, o último dos clérigos presentes nesta zona (v. análise do cancioneiro de João Airas de Santiago).

Este autor tem sido identificado com o Pero Anes Marinho, irmão de Martim Anes Marinho e de Osoiro Anes, e filho de João Froiaz de Valadares (106). Nestas circunstâncias, teríamos que colocar este trovador galego na primeira metade do séc. XIII. A rubrica da suá composição di-lo no entanto, como vimos, filho de João Rodrigues de Valadares. No Livro de Linhagens do Conde D. Pedro aparecem dois indivíduos com este nome, de um dos quais, pelo seu casamento com Teresa Anes Marinha, nasce um Pero Anes Marinho (107). A cronologia deste João Rodrigues deve situar-se na segunda metade do séc. XIII (108). Seu filho, Pero Anes Marinho, terá estado activo, consequentemente, pelos finais do séc. XIII. Um indivíduo com o mesmo nome é mencionado em documentos da Chancelaria de D. Sancho IV como tendo recebido soldada em fins de $1284\left({ }^{109}\right)$. A sua identificacão com o nosso trovador torná-lo-ia contemporâneo de João Vasques de Talaveira e frequentador do mesmo círculo cortesão, permitindo contextualizar as relações que ambos mantiveram com João Airas de Santiago e, finalmente, possibilitando uma definição cronológica mais rigorosa para este último autor.

\section{PERO D'ARMEA (n. ${ }^{\circ s} 35$ e 59)}

Treze cantigas de amor e quatro cantigas de amigo com colocação idêntica à de Airas Pais (v. também Bernal de Bonaval). Possui ainda uma cantiga de escárnio, correctamente colocada na parte inicial do acrescento à respectiva secção.

A sua cantiga de escárnio respondeu Pero Garcia de Ambroa, situando-o no mesmo período, isto é, por volta dos meados do séc. XIII. Tem sido dado como natural de Armea, na Galiza (110). C. Michaëlis parece tê-lo na conta de jogral ou segrel (111).

\section{PERO DE BERDIA (n. $\left.{ }^{\circ} 45\right)$}

Com cinco cantigas de amigo, separa, juntamente com João, jogral de Leão, e Pero Mendes da Fonseca, dois grupos relativamente homogéneos de autores: o primeiro, com cantigas de amor (n.os 29 a

(105) B 935, ed. facs., p. 432; V 523, ed. facs., p. 193.

(106) Tavani, Grundriss, fasc. 8, p. 47 e bibliografia aí mencionada.

(107) LC 25P4, 73DT, 74AJ5.

(108) Sua meia irmã, Luca Rodrigues de Valadares, é abadessa de Arouca nos fins do séc. XIII e inícios do séc. XIV, - Lourenço Soares de Valadares, seu primo, está presente na corte de D. Dinis até 1298. O casamento de Pero Anes Marinho com Beatriz Rodrigues de Lima confirma esta cronologia.

(109) Mercedes Gaibrois de Ballesteros, ob. cit., I, CLVIII.

(110) Tavani, Grundriss, fasc. 8, p. 49.

(111) Michaělis, CA, II, p. 532. 


\section{Revista de História das Ideias}

43), o segundo com cantigas de amigo (n.os 47 a 75 ). A zona em que se insere terá sofrido alguns arranjos, afectando a sua organização anterior (v. João, jogral de Leão, e Pero Mendes da Fonseca). Pelo tipo de composições, é possível que já aí se encontrasse aquando da incorporação de novos autores, estando, neste caso, associado ao segundo grupo acima mencionado. Sobre as ligações a estabelecer entre cronologia e colocação, v. João de Cangas.

Presumivelmente galego e jogral (112). Berdia é topónimo galego. Próximo do rio Tambre, a norte de Santiago, existe uma povoação com este nome.

\section{PERO GOMES BARROSO (n. $\left.{ }^{\circ} 26\right)$}

Presente, com um serventês moral, num grupo heterogéneo de autores situados entre o conjunto inicial de clérigos e um segundo grupo mais homogéneo, iniciado por Pero de Ver (n.o 29). Assinale-se ainda a sua inserção, com outros autores, entre as cantigas de amor e as cantigas de amigo de João Airas de Santiago (n. ${ }^{o s} 18$ e 27). A heterogeneidade do grupo provêm não só da diversidade dos géneros poéticos aí presentes quanto da naturalidade dos próprios autores. A sua origem deve procurar-se na reformulação dessa zona do cancioneiro, em virtude da confluência aí verificada de tradições manuscritas diferentes ( $v$. fichas dos autores correspondentes aos n.os 18-28). No caso particular de Pero Gomes Barroso esta colocação é anormal, porquanto este autor comparece em $\omega$, respeitando a sua divisão por géneros poéticos. A zona da secção das cantigas de escárnio onde se insere foi, todavia, sujeita a acrescentos posteriores. Com efeito, imediatamente após ele surgem João de Gaia, um autor do séc. XIV, João Baveca e João Airas de Santiago, ambos presentes no acrescento à seccão das cantigas de amigo. Ora, nesta secção. Pero Barroso antecede .João Airas com um serventês moral, que estaria certamente associado às suas cantigas de escárnio. Pode admitir-se, consequentemente, um deslocamento desta composição para a sua colocação actual, na altura em que os três autores mencionados são integrados junto de trovadores presentes na secção das cantigas de escárnio de $\omega$.

Cavaleiro português, filho bastardo de Gomes Viegas de Basto, encontra-se, a nartir da década de auarenta do séc. XIII, em Castela, figurando nos repartimentos de Sevilha e Orihuela. As suas cantigas đe escárnio dão-nos conta das suas aventuras e desventuras na corte castelhana. participando, com Afonso $\mathrm{X}$, na crítica aos ricos-homens que, alegando razões diversas, não participaram na guerra contra os muculmanos. Nos inícios da década de setenta mantem-se ainda activo em Castela (113).

\section{PERO GONÇALVES DE PORTOCARREIRO (n. ${ }^{\circ}$ 10)}

Incluído, com quatro cantigas de amigo, no interior do grupo de clérigos da fase inicial deste acrescento. Seguem-se-lhe Pero Goter-

(112) Tavani, Grundriss, fasc. 8, p. 49.

(113) Michaělis, CA, II, pp. 394-8; Henrique David, Os Portugueses e a Reconquista Castelhana e Aragonesa do século XIII, no prelo; Tavani, Grundriss, fasc. 8, pp. 73-4 e bibliografia al indicada. 


\section{«Livro das Cantigas» do Conde D. Pedro}

res, cavaleiro, e D. Estevão Peres Froião. Todos os três quebram a sequência clerical desta zona, devendo admitir-se incorporação ainda mais tardia do que a destes clérigos.

Pero Gonçalves de Portocarreiro, filho, o único com este nome, de Gonçalo Viegas de Portocarreiro, o Alfeirão, «foi mui boo cavaleiro, e morreo sem semel» (114). Seu tio, Reimon Viegas, ficou famoso pela sıı acção no rapto de D. Mécia Lopes de Haro, ocorrido em 1246 (115). A sua actividade deve situar-se, portanto, na segunda metade do séc. XIII. De uma das suas cantigas de amigo depreende-se que esteve ausente em Castela.

\section{PERO GOTERRES, cavaleiro (n. ${ }^{\circ}$ 11)}

Sendo cavaleiro, aparece integrado, com uma cantiga de amor e um serventês contra Deus, no grupo de clérigos postado no início deste acrescento, rodeado por dois nobres portugueses: Pero Gonçalves de Portocarreiro e Estevão Peres Froião (v. respectivas fichas).

Ó nome é vulgar em Portugal. A colocação e os trovadores que o rodeiam permitem-nos pensar tratar-se de um autor português activo na segunda metade do séc. XIII ou ainda nos inícios do séc. XIV. Da sua cantiga de amor infere-se ter estado na corte de um rei português. Pode pôr-se a hipótese de, tal como Estevão Peres Froião e provavelmente Pero Gonçalves de Portocarreiro, se ter ausentado para a corte castelhana. Com efeito, as acusações contra Deus foram um tema glosado nessa corte por outros trovadores. Tavani, apoiado, assim o pensamos, na ed. da obra deste autor por Cesarina Donati, considera-o português e dos finais do séc. XIII e inícios do séc. XIV (116).

\section{PERO MENDES DA FONSECA (n. $\left.{ }^{\circ} 46\right)$}

Incluído, com João, jogral de Leão, e Pero de Berdia, numa zona deste acrescento onde se nota uma organização prévia das composições por géneros poéticos. As suas cinco cantigas de amor, associadas às composições dos autores referidos, quebram um tanto essa organização, surgindo entre as cantigas de amor e as cantigas de amigo aí presentes. Pode pensar-se em insercão ainda mais tardia que deixou, aliás, traços em B. Com efeito antes das suas composicões surge a indicação "Outro $R .^{\circ}$ se começa assy" e, mais abaixo, «R.० par deus senhor quero meu hir" (117), mostrando que o rolo aí incorporado se iniciava com as suas cantigas de amor. Possui ainda uma cantiga de escárnio, colocada no início do acrescento à respectiva secção de $\omega$ (118).

Um dos filhos de um segundo casamento de Mem Gonçalves da Fonseca e padroeiro do mosteiro de Mancelos (conc. de Amarante) (119), Pero Mendes testemunha em Santarém, a 9 de Janeiro de

(114) LC 43B5.

(115) José Mattoso, «Ourém e D. Mécia Lopes de Haro», in A Nobreza Medieval

Portuguesa, Lisboa, 1981, pp. 279-83.

(116) Tavani, Grundriss, fasc. 6 , p. 162 ; fasc. 8 , p. 52.

(117) Antes de B 1122, ed. facs., p. 516.

(118) V., em apêndice, o quadro da zona de interseç̧åo entre $\omega$ e $\alpha$.

(119) LC 66Е1-2. 


\section{Revista de História das Ideias}

1289, as diligências efectuadas por D. Martim Gil e por Lourenço Escola para o escambo do castelo de Portel pela vila de Mafra $\left({ }^{120}\right)$.

\section{PERO MEOGO \\ (n.o 56)}

Nove cantigas de amigo. Sobre a sua colocação e problemas daí decorrentes, v. Fernão do Lago e João de Cangas.

Nome bastante vulgar em Portugal e na Galiza. Foi identificado inicialmente com um clérigo galego do mesmo nome, presente em alguns documentos do terceiro quartel do séc. XIII (121). Luciana S. Picchio (122) parece tê-lo, no entanto, na conta de notário, natural de Santiago de Compostela.

Um notário galego com este nome confirma o testamento de D. Gonçalo Rodrigues de Bendaña, em Fevereiro de 1276 (123).

\section{PERO DA PONTE}

$$
\text { (n. }{ }^{\circ} \text { 23) }
$$

Rodeado por Fernão Padrom e Vasco Rodrigues de Calvelo, surge, com outros autores, após o grupo de clérigos e antes de um novo conjunto de autores, onde se destaca, com poucas excepções, o respeito por uma organização por géneros poéticos. Presente nesta zona com quatro prantos, dois elogios de soberanos e sete cantigas de amor, cinco das quais compareciam também em A. E mais um caso de deslocamento tardio para este acrescento à secção das cantigas de amigo de $\omega$ (v. fichas de Fernão Padrom, Pedr'Eanes Solaz, Vasco Rodrigues de Calvelo e Afons'Eanes do Coton). As suas cantigas de escárnio aparecem, deslocadas, quase no fim do acrescento da respectiva seccão.

Apoiada nas cantigas de escárnio e de maldizer, C. Michaëlis deu já um contributo importante para a definição da biografia deste autor. A sua actividade situa-se essencialmente no segundo quartel do séc. XIII, embora possa ter prosseguido nos inícios da sua segunda metade. A ligação profissional a Bonaval e a Coton, referida em composições de Afonso $X$, dá-lhe como naturalidade quase segura a Galiza. $\mathrm{Na}$ sua condicão de segrel - atribui-se, numa tencão com Coton, a categoria de escudeiro - terá frequentado as cortes de alguns magnates peninulares e também. pelo menos, as cortes régias de Fernando III e de Afonso X (124).

\section{PERO DE VER (n.os 29 e 48)}

A disposição das suas composições (duas cantigas de amor e seis cantigas de amigo) é idêntica à de Airas Pais (v. também Bernal de Bonaval).

(120) Livro dos Bens de D. João de Portel (Cartulário do séc. XIII), ed. por Pedro de Azevedo e Anselmo Braancamp Freire, Lisboa, 1910, p. LXXV.

(121) J. Figueira Valverde, aNuevos rastros documentales de juglares gallegos», Cuadernos de estudios gallegos, I, Santiago de Compostela, 1944, pp. 137-8.

(122) Luciana Stegagno Picchio, La methode philologique I. La poesie, Paris, 1982, pp. 144.

(123) Manuel Lucas Alvarez, El Monasterio de San Salvador de Camanzo (sep. de AArchivos Leoneses», 64, 1978) Leon, 1978, doc. 19.

(124) Michaëlis, CA, II, pp. 450-64. V. tb. Tavani, Grundriss, fasc. 8, pp. 47.9 e bibliografia al indicada. 
Os topónimos Ver e Gião, este último presente nas suas cantigas de amigo, são comuns a Portugal e à Galiza (125). Em 1236, um Pero de Ver e seus irmãos doam à Sé do Porto o direito de padroado que possuem sobre a igreja de Lamas ${ }^{(126)}$. Pode não se tratar porém do nosso autor. Estamos perante um problema de identificação idêntico ao de Martim de Ginzo, somente resolúvel quando ao nome se seguir a indicação de uma actividade no meio trovadoresco. A análise da estratigrafia deste acrescento poderá lançar alguma luz sobre a sua cronologia e naturalidade.

\section{RODRIGU'EANES D'ALVARES (n. 21)}

Surge apenas com uma cantiga de amigo, na zona mais conturbada deste acrescento (vejam-se, a título de exemplo, os casos de João Airas de Santiago, Fernão Padrom e Pero Gomes Barroso). Inclusão, de qualquer modo, tardia, na sequência do grupo de clérigos que o antecedem ou mesmo após o longo grupo de autores presentes, na segunda metade deste acrescento, com cantigas de amor e cantigas de amigo.

Cavaleiro português activo, pelo menos, no segundo e terceiro quartéis do séc. XIII. Natural de Alvares, perto de Lamego, as Inquirições de 1258 dão-nos dele a imagem de um nobre turbulento, cioso dos seus interesses e temido em Tarouca pelos homens do rei (127). Em 1269, testemunha uma confirmação de Pero Anes Gago ao mosteiro de Tarouca (128). Enre as datas mencionadas - ou após 1269 - ausentou-sé da sua região e, eventualmente, do país, segundo se pode depreender da sua cantiga de amigo.

\section{RUI FERNANDES, clérigo \\ (n. 14 e (?) 8)}

Colocado, com sete cantigas de amigo, no grupo de clérigos da parte inicial deste acrescento. Tem sido identificado com o Rui Fernandes de Santiago presente em A e também no início deste acrescento (n..$^{\circ}$ ). Neste caso, os problemas levantados pela sua colocação seriam idênticos aos de Martim Moya (v. ficha respectiva) e a existência de duas tradições manuscritas encontrar-se-ia justificada pelas duas denominações deste autor.

Clérigo de Santiago de Compostela, Rui Feranndes teria vivido por volta de meados do séc. XIII. Segundo Lopez Ferreiro, seria o mesmo a quem Afonso $X$ nomeou seu capelão e que, em Dezembro de 1273, mandava fazer o seu testamento em Salamanca (129).

\section{RUI MARTINS}

$$
\text { (n. } 27 / 2 \text { ) }
$$

A sua única composição, uma tenção incompleta com João Airas de Santiago, encontra-se inserida na obra deste autor.

(125) Nunes, Amigo, I, pp. 242-4; III, pp. 632-3.

(126) Censual do Cabido da Sé do Porto, ed. da Biblioteca Pública Municipal do

Porto, Porto, 1922, pp. 231-2.

(127) Inq., pp. 1074b e 1075a.

(128) TT - Ch. Dinis, L. V, fl. 75.

(129) Tavani, Grundriss, fasc. 6, p. 159; fasc. 8, p. 54; Antonio Lopez Ferreiro, ob. cit., v, p. 376; Micharlis, CA, II, pp. 476-8 e 582. 
Dessa tenção deduz-se que era contemporâneo de João Airas, ou seja, segundo a nova cronologia que propomos para este autor, da segunda metade ou mesmo de finais do séc. XIII e que era, provavelmente, leonês. A sua condição de jogral pode retirar-se, pela indicação do seu nome primitivo, da rubrica que acompanha, em $V$, a mesma composição: «Esta tençon fez Joan Âras de Santiago a un que avia nome Fruitoso Canton e se pôs nome Rui Martiiz, e o outro respondeu-lhi» (130).

\section{RUI MARTINS DO CASAL}

(n.9 52)

Está inserido, com três cantigas de amor e três cantigas de amigo, num grupo de autores presentes nessa zona apenas com cantigas de amigo. Sinal evidente de uma incorporação ainda mais tardia do que a desses autores. A situação de João Zorro, autor que o antecede, é idêntica à sua. A reformulação desta zona levou a que, numa fase já posterior ao período da cultura trovadoresca, fosse aí acrescentado um novo autor (n. 53$)$.

Cavaleiro português proveniente de uma linhagem com ligações ao mosteiro de S. Simão da Junqueira, próximo de Vila do Conde (131). Vários documentos de finais do séc. XIII atestam a sua presença nessa altura em Santarém, onde possuía alguns bens. Morre no mosteirn de Tarouquela, no início de $1312\left({ }^{132}\right)$. De duas das suas cantigas d $\epsilon$ amigo deduz-se que esteve algum tempo em Castela (133).

\section{RUI MARTINS D'OLIVEIRA}

$$
\text { (n.०25) }
$$

Presente na zona mais conturbada deste acrescento com uma cantiga de amor e três cantigas de amigo (para se ter uma ideia dos elementos diversos aí reunidos v. João Airas de Santiago, Fernão Padrom e Pero Gomes Barroso). A sua incorporação tardia deve ter ocorrido na mesma altura das de Rodrigu'Eanes d'Alvares e Martim Peres Alvim, inseridos também nessa mesma zona.

Um cavaleiro com este nome testemunha um documento em Guimarães, no ano de 1280 (134). E certamente o mesmo que o Rui Martins de Oliveira mencionado no Livro de Linhagens do Conde D. Pedro em virtude do seu casamento com Sancha Anes de Sandim (135), filha de um bastardo de Paio Pires de Guimarães. Estava, neste caso, ligado pelo parentesco a Martim Peres Alvim, trovador seu contemporâneo, porquanto a mãe de Sancha Anes era irmã da mãe de Martim Peres.

\section{SANCHO SANCHES, clérigo (n.ं17)}

Conclui, com uma cantiga de amor e cinco cantigas de amigo, o grupo de clérigos inserido na parte inicial do acrescento em análise.

(130) V 642, ed. facs., p. 232.

(131) Eugenio Andrea da Cunha e Freitas, eGeraçóes medievais portuguesas. Cavaleiros e escudeiros do Casal», Anais da Academia Portuguesa de Historia, t. XII, 1962 , pp. 199-203.

(132) Biblioteca Geral da Universidade de Coimbra, c6d. 703, p. 123.

(133) B 1162 e 1163, ed. facs., pp. 531-2; V 765 e 766, ed. facs., pp. 268-9.

(134) TT, Tarouquela, VIII (por amável indicaçåo do Prof. Doutor José Mattoso).

(135) LC 45P3. 


\section{«Livro das Cantigas» do Conde D. Pedro}

Surge ainda na secção das cantigas de amor de $\omega$, com uma cantiga de amor incompleta (v. Nuno Porco e Pero Garcia de Ambroa). Uma variante da mesma composição é, no entanto, atribuída a Pero da Ponte, no acrescento à secção das cantigas de amigo (n. $\left.{ }^{\circ} 23\right)$.

Nada se sabe de concreto acerca deste autor. Dada a naturalidade dos restantes clérigos presentes na mesma zona será, provavelmente, galego ou castelhano. Quanto à sua cronologia, veja-se a análise global à obra destes autores.

\section{VASCO RODRIGUES DE CALVELO \\ (n. 24$)$}

Colocado entre Pero da Ponte e Rui Martins d'Oliveira, com nove cantigas de amor, quase todas presentes na parte final de A. Trata-se, mais uma vez, de um deslocamento de composições de A para esta zona do cancioneiro (v. Fernão Padrom e Pero da Ponte, e também Martim Moya, Pedr'Eanes Solaz e Rui Fernandes de Santiago).

Dada a sua presença em $\omega$, quer na secção das cantigas de amor quer na secção das cantigas de amigo ${ }^{(136)}$, a sua cronologia nunca se estenderá para além do séc. XIII. Em virtude disso, não poderá ser identificado como o cavaleiro do mesmo nome que, em Abril de 1326, acede a uma venda feita pela mulher, Elvira Fernandes, ao mosteiro de S. Pedro de Rocas, no sul da Galiza (137). Nas inquirições de 1258 , no julgado de Penela, duas filhas de um Vasco Rodrigues, sem indicação do nome de família, são criadas em S. Maria de Duas Igrejas, povoação muito próxima de Calvelo (138). Podendo ser o nosso autor, pertenceria, de qualquer modo, a uma linhagem sem grande importância social. Com o mesmo apelido, os livros de linhagens medievais portugueses registaram apenas Mor Martins de Calvelo, pelo facto de ter casado com Fernão Guedaz ${ }^{(139)}$, pai de Fernão Fernandes Cogominho.

(136) V., em apendice, o quadro da zona de intersecçăo entre $\omega$ e $\alpha$.

(137) Emilio Duro Peffa, El monasterio de San Pedro de Rocas y su coleccion documental, Orense, 1972, doc. 62.

(138) Inq., p. 4006 .

(139) LC 30BA3. 